Published as: Marten, Lutz and Jenneke van der Wal. 2014. A typology of Bantu subject inversion. Linguistic Variation 14(2): 318-368.

\title{
A typology of Bantu subject inversion
}

\begin{abstract}
This study charts variation in subject inversion constructions in Bantu languages. It distinguishes between seven types of inversion constructions: formal locative inversion, semantic locative inversion, instrument inversion, patient inversion, (clausal) complement inversion, default agreement inversion and agreeing inversion. Based on a set of nine surface variables, a matrix of inversion constructions is developed which identifies characteristics of the set of constructions overall as well as of each individual construction type. The distribution of the different inversion constructions is documented with reference to a sample of 46 Bantu languages, from which geographical and typological generalisations are drawn. For example, languages with instrument inversion or with patient inversion always have locative inversion (but not vice versa), or if a language has at least one inversion construction, it always has at least either default agreement inversion or agreeing inversion. Finally, underlying parameters potentially accounting for the variation are discussed, such as the status of preverbal locatives as DP or PP, the agreement parameter and the syntactic and thematic restrictions on the preverbal element.
\end{abstract}

Keywords: agreement, Bantu, information structure, inversion, subject, typology, variation, word order

\section{Introduction}

Bantu languages are fairly uniform in broad morphosyntactic parameters. They can be characterised as head-marking, having basic SVO but partly pragmatically determined word order, with an articulated noun class and agreement system, and complex verbal 
extensions. Bantu languages exhibit qualities of a linguistic spread zone (e.g. Nichols 1992, Dixon 1997) and convergence zone (Marten 2013) with an overall high degree of morphosyntactic similarity. However, within this harmony, additional, exceptional and unexpected features are found, and there is a rich tapestry of morphosyntactic microvariation.

Previous studies of morphosyntactic variation in Bantu have focussed on topics such as applicative and double object constructions (e.g. Bresnan and Moshi 1990, Rugemalira 1993), subject and object marking (Beaudoin-Lietz et al. 2004, Marten et al. 2012), relative clauses (Nsuka Nkutsi 1982, Henderson 2006) or word order (Buell et al. 2011), while Marten et al. (2007) develop a broader approach of twenty parameters of variation.

A particular well-known domain of variation are locative inversion and presentational constructions, and several studies have shown the considerable variation between different Bantu languages with respect to these constructions (e.g. Bresnan and Kanerva 1989, Demuth and Mmusi 1997, Marten 2006, 2011, Zerbian 2006, Khumalo 2010, Salzmann 2011, Creissels 2011, van der Wal 2008, 2012, Marten and Gibson 2013, Ngoboka and Zeller 2013, Zeller 2013).

The present paper takes previous studies of these two types of inversion constructions as a starting point, but shows that there is a large range of related construction types which need to be taken into account for a comprehensive understanding of inversion constructions in Bantu. These include (semantic) locative inversion, instrument inversion, patient inversion (subject-object reversal), complement inversion, default agreement inversion and agreeing inversion. In addition, we briefly consider passives and subject inversion in object relatives, as more remotely related cousins. All inversion constructions share the property that the logical subject follows the verb. They can be differentiated along different dimensions, such as promotion of a non logical-subject argument to 
preverbal position, presence or absence of verbal agreement with the logical subject, and formal marking of the inversion construction. In addition, a number of construction types are distinguished by the thematic role of the non logical-subject argument taking part in the inversion construction. A summary of the main invariant common characteristics and variable features of inversion constructions is given here, and will be motivated and further discussed in the following sections. The constant characteristics of core subject inversion constructions are:

1. The logical subject follows the verb and cannot be omitted

2. The postverbal subject is non-topical (but often underspecified for narrow subject focus or use as a thetic sentence)

3. Object marking is not possible

4. Close 'bonding' between verb and postverbal DP is often indicated in phonological phrasing, absence of augment, conjoint verb form, or complement tone pattern

Differences between subject inversion constructions come about through differences along a set of variable features:

5. Morphological marking of the preverbal phrase

a. Locative marking

6. Thematic restrictions on the preverbal phrase
a. Locative
b. Instrument
c. Patient
d. Proposition 


\section{Agreement}
a. Agreement with the preverbal DP/'topic'/clause
b. Default (locative) agreement
c. Agreement with the inverted logical subject

8. Word order
a. VS only
b. VS and VOS
c. VS and VSO

Based on these characteristics, we distinguish seven subject inversion constructions: Formal Locative Inversion (FLI), Semantic Locative Inversion (SLI), Instrument Inversion (InsI), Patient Inversion (PatI), Complement Inversion (CmpI), Default Agreement Inversion (DAI), and Agreeing Inversion (AI), and we discuss passives as a related construction (PASS).

After presenting a survey of the relevant inversion constructions, we develop a set of variables to formally distinguish the different construction types. We then chart variation in inversion constructions across Bantu based on a sample of 46 Bantu languages and show geographical and typological generalisations arising from the comparative study. A final part of the paper is concerned with relating the differences presented to a more abstract set of underlying parameters of variation, showing how at least some of the surface variation observed results from differences in changes in the morphosyntax of locative marking in different Bantu languages, differences in agreement systems, and lexical and thematic restrictions on inversion constructions.

The paper has descriptive, comparative and theoretical aims. It presents a comprehensive survey of Bantu inversion constructions and distinguishes and illustrates 
several different inversion construction types. Inversion constructions are common in Bantu and so the study provides a good indication of the variation and complexity of the construction type cross-linguistically. The comparative part of the study shows the distribution of the construction across an empirical base of 46 Bantu languages. Results of this comparison provide an indication of the geographic and typological spread of the constructions and feed into wider comparative Bantu studies concerned with morphosyntactic variation. On the theoretical level, the paper raises questions about how considerable surface variation can captured systematically and to what extent it can be reduced to more abstract, underlying parameters of variation, as has been proposed in much of formal syntax over the last decades. The study shows that this is (still) a worthwhile undertaking, but that specific, verifiable results can only be achieved on the basis of more empirical and analytical work.

The paper is organised as follows. Section 2 provides a brief background to relevant aspects of the morphosyntax of Bantu languages. Section 3 introduces formal locative inversion: As this is the most well described Bantu inversion construction, we take this as our starting point and set out issues which will be relevant for the comparative study which follows. Section 4 is a survey of other inversion constructions found in Bantu and notes specific features of the constructions. Section 5 discusses default agreement inversion and agreeing inversion, which, unlike the other inversion constructions, do not have a preverbal DP. Section 6 develops a set of criteria to jointly describe Bantu inversion constructions, and to distinguish different inversion constructions from each other. Section 7 presents a comparative study of 46 Bantu languages comparing the presence of different construction types in different languages, and presents generalisations based on the distribution. Section 8 turns to the possible sources for the 
variation in terms of underlying parameters. Section 9 presents conclusions and perspectives for future work.

\section{Morphosyntactic background}

Bantu languages are characterised by articulated noun class systems and complex verbal morphology. Most Bantu languages have around 15-18 noun classes which can be distinguished by nominal noun class prefixes, paradigmatic relationships between classes (e.g. singular-plural pairings), agreement morphology on verbs, adjectives and dependent nominals, and, to a lesser extent, semantic criteria (cf. Maho 1999, Katamba 2003). Noun class systems typically include locative classes which will be discussed in more detail in the following section. Verbal morphology includes inflectional affixes - most of them prefixes - typically expressing agreement, tense-aspect, and negation, and a set of derivational suffixes (sometimes called 'extensions') including applicative, causative and passive markers. In the Swahili example in (1) watoto 'children' is in noun class 2, as shown by the prefix wa-, the concord $w(a)$ - on the modifier -ote 'all', and the agreement on the verb as the subject marker $w a-$. The verb shows prefixal agreement (wa-) and tense (na-) marking, as well as a derivational passive suffix $-w$ - and a final inflectional morpheme - $a$, which for want of a better explanation is glossed as 'Final Vowel':
(1) Wa-toto w-ote wa-na-fundish-w-a
Ki-swahili.
[Swahili]
2-children 2-all SM2-PRS-teach-PASS-FV 7-Swahili
'All (the) children are taught Swahili.'

Of particular relevance to the ensuing discussion is the notion of subject, as we will be concerned with subject inversion. Grammatical subjects in Bantu can be identified most 
easily by agreement with the verbal subject marker, such as $w a$ - in (1), while other, often language-specific, tests for subjecthood include NP-modification and relative clauses only available to subjects, raising constructions, or, possibly, prosodic marking. Morphological case marking of grammatical function is absent in Bantu and does not play a role for identifying grammatical subjects.

In our analysis, we contrast grammatical subjects from logical (or semantic) subjects, a notion we adopt from formal semantics, where a logical subject of a proposition may be defined as the argument combining last with the predicate to yield a proposition (Cann et al. 2009, Gamut 1991). In the constructions discussed in this paper, the expression denoting the logical subject follows the verb in terms of linear order, and some other nominal expression may or may not function as the grammatical subject. Next to distinguishing between a grammatical and a semantic level of analysis, we identify a thematic level, and use terms such as agents, locations, and patients. The logical subject may be the agent of a predicate, but this it not necessarily so. In John fell, for example, John is not the active agent, but we still refer to John as the logical subject. These distinctions can be incorporated in different ways in different theoretical models, but this is not our central concern here. However, the distinction between syntactic and semantic roles will turn out to be useful for the present discussion.

Another distinction that needs to be drawn is that between subjects and topics, on which there is a long-standing discussion concerning Bantu languages. There are two points of view one can take here: the structural and the interpretational. In the structural view, there are two separate hierarchical positions in the sentence, one for the (syntactic) subject and one, generally more peripheral, dedicated topic position. Since they result in the same linear position, it is often a matter of debate which structural position a preverbal element occupies. We will not be concerned much with the structural distinction, as this 
would require a more detailed discussion of syntactic assumptions which are not central for the present paper. Instead, when we refer to 'topic' we take the interpretational view and take the topic to be 'what the sentence is about'. Linguistic elements can have this topic interpretation in the sentence-peripheral position as well as the syntactic subject position.

Another difficulty in linear order is the fact that postverbal logical subjects can be in various structural positions. Typically, they can be either 'internal', being in a position inside the verb phrase, or 'external' (dislocated). The diagnostics to establish whether a linearly postverbal subject is internal or external include the following:

1. Prosodic evidence: if phonological phrasing maps onto syntactic phrasing, the subject is inside the verb phrase if the verb and the postverbal subject are phrased together.

2. Morphological evidence: the conjoint/disjoint alternation and various inflectional nominal tone patterns have been shown to express the closer or looser bond between the verb and the following element, so if the postverbal subject occurs with the same morphological form as an object would in a neutral transitive clause, this is evidence for the internal position of the subject.

3. Syntactic evidence: if a language allows transitive inversions (VSO/VOS), the relative scope and binding facts of the subject and object can show whether the subject is in-situ in the verb phrase. Unfortunately, not all languages allow for this, and for most languages, the scope and binding data are not available. 
The distinctions between semantic, syntactic and pragmatic roles will become clear when we look at the data in more detail. In the following section, we will begin our survey of Bantu inversion constructions with a discussion of formal locative inversion.

\section{Formal locative inversion}

Bantu locative inversion has been intensively studied (e.g. Bresnan and Kanerva 1989, Demuth and Mmusi 1997, Marten 2006, Khumalo 2010, Salzmann 2001, 2011, Creissels 2011). Following Buell (2007), we occasionally refer to this type of locative inversion as 'formal locative inversion' to distinguish it from 'semantic locative inversion', discussed in the next section.

Formal locative inversion has a number of characteristic features, which we come back to in our comparative overview of the various inversion constructions in section 6 :

1. The postverbal DP expresses the logical subject and cannot be omitted

2. The postverbal DP is non-topical (thetic sentence or subject focus)

3. Object marking is not possible: No object marker either referring to the postverbal logical subject or to a remaining postverbal object is permitted

4. The postverbal DP cannot be separated from the verb; the verb and the postverbal DP are phonologically phrased together

5. The preverbal DP is marked as a locative

6. The locative DP is the grammatical subject, agreeing with the verb

7. Availability of locative inversion is dependent on predicate type 
An illustration of many of these features can be provided from Otjiherero (Möhlig et al. 2002, Marten 2006, Möhlig and Kavari 2008):

(2) a. È-rúngá r-á hìtí m-ón-djúwó.

[Otjiherero]

5-thief SM5-PST enter 18-9-house

'The thief entered the house.'

b. M-òn-djúwó mw-á hìtí é-rùngà.

18-9-house SM18-PST enter 5-thief

'Into the house entered a/the thief.'

In the transitive clause in (2a), the logical subject (and agent) is coded as grammatical subject, and the locative follows the verb. In the locative inversion construction in (2b), the locative precedes the verb and triggers agreement, while the agent is expressed by the postverbal DP. The locative DP is morphologically marked as locative by an appropriate noun class prefix (here of class 18), and the agreeing subject marker $m w$-belongs to the same class.

The postverbal DP is essential for the construction and cannot be omitted (3), unless the predicate is passivised (4) or can be construed as impersonal (5). In this case the construction is strictly speaking no longer an inversion construction, since no expression for the logical subject follows the verb, and might better be considered as a kind of middle construction (see e.g. Kemmer 1993). ${ }^{2}$ 


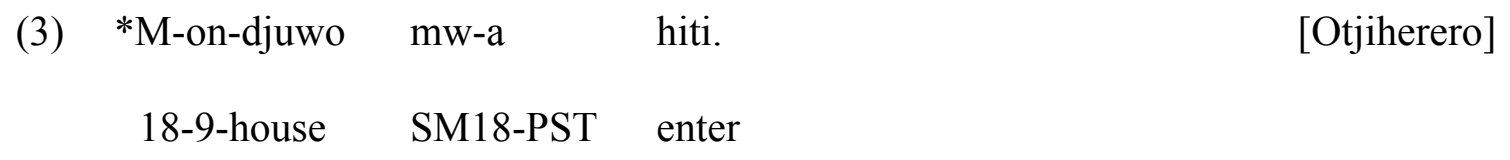

(4) M-òngàndà mw-á-hìt-w-á.

18-9.house SM18-PST-enter-PASS-FV

'Into the house was entered/the home was entered.'

(5) Pò-ngàndá pé-térék-à.

16-9.house SM16.HAB-cook-FV

'At home there is usually cooking going on/being cooked.'

In contrast, the locative DP can be omitted if the locative reference can be reconstructed from the context:

(6) Mw-á-hìtí é-rùngà.

[Otjiherero]

SM18-PST-enter 5-thief

'In there (i.e. a place we've been talking about) entered a thief.'

Object marking is impossible in locative inversion, either of the postverbal logical subject DP (7b) or of a theme argument $(7 c, d)$, as the examples from Ndebele show (Langa Khumalo, p.c.). However, the postverbal DP in Otjiherero can be pronominalised by a postverbal pronominal clitic $(8 \mathrm{~b}):^{3}$ 
(7) a. Ku-kha aba-ntwana ama-nzi

[Ndebele]

SM17-draw 2-children 6-water

'There are children drawing water'

b. *Ku-ba-kha aba-ntwana ama-nzi

SM17-OM2-draw 2-children 6-water

c. *Ku-a-kha ama-nzi aba-ntwana

SM17-OM6-draw 6-water 2-children

d. *Ku-a-kha aba-ntwana ama-nzi

SM17-OM6-draw 2-children 6-water

(8) a. *M-on-djuwo mw-a ri hiti.

[Otjiherero]

18-9-house SM18-PST OM5 enter

Intd.: 'Into the house entered s/he.'

b. M-òn-djúwó mw-á hìtí=rò.

18-9-house $\quad$ SM18-PST enter=PRO5

'Into the house entered s/he.'

On the phonological level, the postverbal DP is often marked as being closely bound to the verb. In Otjiherero, the DP is marked tonally by the 'complement tone pattern' which is also found on objects, and not by the 'default tone pattern' which is found, for example, 
on right-dislocated subjects (cf. Kavari et al. 2012 for nominal inflectional tone patterns, or 'tone cases', in Otjiherero):

$\begin{array}{lllll}\text { (9) M-òn-djúwó } & \text { mw-á } & \text { hìtí é-rùngà / *è-rúngá. } \\ \text { 18-9-house } & \text { SM18-PST enter } & \text { 5CC-thief } & \text { 5DC-thief }\end{array}$

'Into the house entered a/the thief.'

In Chichewa (Bresnan and Kanerva 1989: 9), phonological lengthening of the penultimate vowel indicates the right edge of a phonological phrase. This lengthening is absent on the verb in locative inversion, showing that the verb and the postverbal DP are phrased together (indicated by brackets):

a. (Ku-mu-udzi) (ku-na-bwér-á a-lendó átáàtu)

[Chichewa]

17-3-village SM17-PST-come-FV 2-visitor those

'To the village came they, those visitors'

b. *(Ku-mu-udzi) (ku-na-bwéèr-a) (a-lendó átáàtu)

17-3-village SM17-PST-come-FV 2-visitor those

Intd.: 'To the village came they, those visitors'

Locative inversion constructions are also associated with particular pragmatic or information structure effects. While the preverbal locative serves as a background topic or scene-setting topic, the postverbal DP is typically discourse-new and presented as new information (11). Locative inversion can also be used to introduce inherently focused wh pronouns (12). 

(11) Kò-mù-tí kw-á pósé òzón-djìmá [Otjiherero] 17-3-tree SM17-PST make_noise 10-baboon
'In the tree the baboons made noise'
(12) Mò-n-gàndá mw-á hìtí ùné? 18-9-house SM18-PST enter who 'Into the house entered who?'

Locative inversion constructions are often contrasted with default agreement constructions (further discussed in Section 5). Both share the pragmatic function of introducing new information, but while in locative inversion a particular location is implied where the action takes place, in default agreement constructions, a grammaticalised former locative subject marker functions as a default subject marker.

(13) Gó tsàmá-1́lé Mphó.

[Tswana]

SM17 go-PRF.CJ Mpho

'There has gone Mpho.' (Creissels 1996: 113)

(14) P-à-rí

òmú-rúmèndú w-à-t-íré

[Otjiherero]

SM16-REMIMPFV-be 2-man SM1-REMPERF-die-PRF

ná péndúkà.

and resurrect

'There (once) was a man (who) died and resurrected.' (Möhlig et al. 2002: 105) 
A final aspect of locative inversion constructions (and default agreement constructions) is that cross-Bantu, there is variation as to the predicate type which can participate in the constructions. Several comparative studies (Bresnan and Kanerva 1989, Demuth and Mmusi 1997, Marten 2006, Khumalo 2010, Salzmann 2001) have shown that while some languages, such as Otjiherero and Ndebele, do not impose any restrictions, in other languages, only a subset of verbs participate in the construction: Sesotho and Setswana do not allow active transitives, Chishona in addition bars active unergatives, while in Chichewa and Kichaga only unaccusatives and transitive passives are allowed, and in ciLuba, the construction is restricted to the copula. ${ }^{4}$ This variation in predicate type in locative inversion and default agreement constructions is illustrated in Table 1.

\begin{tabular}{|c|c|c|c|c|c|c|}
\hline & $\begin{array}{l}\frac{\pi}{\Xi} \\
\stackrel{\Xi}{\Xi}\end{array}$ & 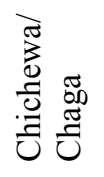 & 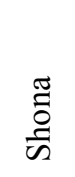 & 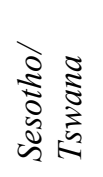 & 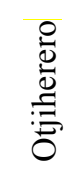 & $\frac{\frac{\Xi}{\Xi}}{\frac{\Xi}{\Xi}}$ \\
\hline Copula 'be' & OK & $\mathrm{OK}$ & $\mathrm{OK}$ & OK & OK & $\mathrm{OK}$ \\
\hline Unaccusative active & $*$ & OK & $\mathrm{OK}$ & OK & $\mathrm{OK}$ & OK \\
\hline Transitive passive & * & OK & $\mathrm{OK}$ & $\mathrm{OK}$ & OK & OK \\
\hline Unaccusative passive & $*$ & $*$ & $\mathrm{OK}$ & OK & OK & OK \\
\hline Unergative passive & $*$ & $*$ & $\mathrm{OK}$ & $\mathrm{OK}$ & OK & OK \\
\hline Unergative active & $*$ & $*$ & $*$ & $\mathrm{OK}$ & OK & OK \\
\hline Transitive active & * & * & * & $*$ & $\mathrm{OK}$ & OK \\
\hline
\end{tabular}

Table 1: Inversion variation with respect to predicate type (italics: default agreement inversion) 
Having laid out the basic characteristics of Bantu locative inversion constructions, in the next section we will show that there is a range of related inversion construction types which share central qualities with locative inversion.

\section{Related inversion constructions}

In this section we will survey a range of constructions which all share the property that the logical subject follows the predicate. These are semantic locative inversion, instrument inversion, patient inversion (subject-object reversal), complement inversion, and quotatives. The majority of the constructions differ from each other in - and can be characterised by - the restrictions on the thematic role of the preverbal DP which is coded as grammatical subject. This is the case for locative, instrument, and patient inversions. Complement and quotative inversion involve verbs which take clausal complements, which in inversion constructions precede the verb.

We will also briefly discuss object relatives and passives, which are in several respects different from the rest of the inversion constructions discussed here, but share some of their central properties and are so included here as distinct but related construction types. Subject inversion in object relatives is related to the surrounding relative-clause structure, and results in part from the morphology of different relative clause markers (Demuth and Harford 1999, Harford and Demuth 1999, Zeller 2004, Henderson 2006). In passives, the logical subject is typically optional and encoded by a prepositional phrase, and there is often special morphological marking of the verb. However, there are a number of parallels between these last two and the more central inversion constructions which we point out in the course of the discussion.

In the following sections, we briefly describe each of the inversion construction types. 


\subsection{Semantic locative inversion}

One criterion of formal locative inversion as described in Section 3 is that the initial DP is formally marked as a locative DP and that the verb agrees with it in locative noun class through a locative subject marker. In contrast, in semantic locative inversion (Buell 2007), the initial DP is a locative DP in terms of reference, but is not marked formally as locative, as the following examples from Zulu and siSwati show:

$\begin{array}{llllll}\text { (15) Lezi } & \text { zindlu } & \text { zi-hlala } & \text { aba-ntu } & \text { aba-dala. } & \text { [Zulu }] \\ \text { 10.these } & \text { 10.houses } & \text { SM10-live } & \text { 2-people } & \text { 2-old }\end{array}$

'Old people live in these houses.' (Buell 2007: 108)

(16) Ipulatifomu i-ma aba-ntu aba-win-ile.

9.platform SM9-stand 2-people REL2-win-PRF

'The winners stand on the platform.' (Buell 2007: 111)

(17) Le-si si-kole si-fund-ela izingane ezikhubazekile.

DEM-7 7-school SM7-study-APPL 10.children 10.handicapped

'Handicapped children study at this school.' (Buell 2007: 110)

(18) Le-si-kolo le-si-sha si-to-fundza ba-ntfabenkhosi [siSwati]

DEM-7-school DEM-7-new SM7-FUT-read 2-children.of.king

'The king's children will study at the new school' (Thwala 2006b: 213)

In (15-18) the grammatical subject belongs to a non-locative class $(10,9$, and 7 , respectively) but semantically refers to a location. The verb shows agreement in class, and 
the logical subject follows the verb. The construction closely resembles formal locative inversion, except for the absence of locative coding of the grammatical subject. In southern Bantu languages, the historic locative classes have been lost (Marten 2010), and the presence of semantic locative inversion in Zulu and siSwati shows that locative inversion is independent of the morphosyntax of locative marking. However, semantic locative inversion appears also to be found in languages with do have formal locative marking, such as Swahili and Olutsootso, which in addition also have formal locative inversion. In Swahili, for example, both semantic locative inversion (19) and formal locative inversion (20) are possible:

$\begin{array}{lll}\text { Ki-wanja } & \text { ki-na-tu-a } & \text { ndege } \\ \text { 7-field } & \text { SM7-PRS-land-FV } & \text { 9.plane }\end{array}$

'An aeroplane has landed on the airfield.'

(Whiteley and Mganga 1969: 117, Russell 1985: 477)

\begin{tabular}{|c|c|c|}
\hline (20) & Ki-wanja-ni & pa-na-tu-a \\
\hline & 7-field-LOC & SM16-PRS-land-FV \\
\hline
\end{tabular}

'In this field has landed an aeroplane.'

(Yussuf Hamad, p.c. May 2013)

There are pragmatic differences between the two constructions - for example, in (20) with a formally coded locative, the location is emphasised, while (19) has an implication of surprise sometimes associated with thetic statements (see discussion in 4.3, below). However, more work on the exact meaning and use of the constructions is needed, and for the present discussion we simply note the presence of the two construction types in 
Swahili, and will return to the question of the relation between formal locative inversion and semantic locative inversion from a comparative Bantu perspective in section 7 below.

\subsection{Instrument inversion}

In instrument inversion, the grammatical subject is a thematic instrument and the verb shows agreement with it (Thwala 2006a, 2006b, Zeller 2012):

(21) Isi-punu si-dl-a u-John.

[Zulu]

7-spoon SM7-eat-FV 1a-John

'John is using the spoon to eat.' (Lit.: 'The spoon is eating John.') (Zeller 2012: 134)

(22) Imali i-dlal-a bantfwana ka-Gates.

[siSwati]

4.money SM4-play-FV 2.children LOC-Gates

'Children play with money at Bill Gates' home.' (Thwala 2006b: 213)

(23) Le-moto le-na i-to-hamb-a tsine kuphela.

DEM-9.car DEM-9 SM9-FUT-go-FV us only

'Only we will travel in this car.' (Thwala 2006b: 213)

(24) Ikaramu y-andikish-a John.

[Kirundi]

9.pen SM9-write-FV 1.John

'It is John who writes with a pen.'

(Ferdinand Mberamihigo, p.c. March 2013) 
Like in semantic locative inversion, the instrument phrase is not morphologically marked and the construction is characterised by the semantic (or thematic) qualities of the initial DP. For Zulu, Zeller (2012) notes that instrument inversion is licensed by prototypical, expected instruments associated with the event, e.g. a spoon in the context of cooking.

\subsection{Patient inversion (subject-object reversal)}

Patient inversion is better known in the literature as subject-object reversal, ${ }^{5}$ and, with the possible exception of locative inversion, the construction has been described and analysed more extensively than other inversion constructions (Whiteley and Mganga 1969, Bokamba 1979, Russell 1985, Ndayiragije 1999, Morimoto 2000, 2006, Henderson 2011, Marten and Gibson 2013, among others). Our choice of the term 'patient inversion' is in keeping with our use of thematic roles for classifying inversion constructions.

Similar to other inversion constructions, in patient inversion, a direct object bearing a patient thematic role in a transitive construction becomes the subject of the corresponding inversion construction, while the logical subject follows the verb:

(25) a. Imw-ana ka-tula ici-ya.

1-child SM1-broke 7-pot

'The child broke the pot.'

b. Ici-ya ci-tula imw-ana.

7-pot SM7-broke 1-child

'The child broke the pot.' (Lit.: 'The pot broke the child.') (Mkude 1974: 133) 
Much has been written about the use of and restrictions on patient inversion. Semantically, it has been noted for Kirundi and Kinyarwanda that the two arguments of the verb need to differ in animacy, and that the logical subject needs to be higher in animacy (Kimenyi 1980, Morimoto 2000, 2006). Pragmatically, the construction shares aspects of locative inversion: the initial DP often provides the background of the assertion, and there is focus on the postverbal subject:

\author{
(26) Ama-tá y-á-nyôye abâna \\ [Kirundi] \\ 6-milk SM6-PST-drink.PRF 2.children \\ 'Children (not parents) drank milk.' (Lit.: 'Milk drank children.')
}

(Ndayiragije 1999: 400)

For Kinyarwanda, Kimenyi (1980: 141-146) argues that the preverbal DP is not a subject, but functions as a topic and does not have typical subject properties. In fact the only subject property of preverbal DPs in patient inversion, according to Kimenyi (1980), is verbal agreement. Morimoto $(2000,2006)$ correspondingly proposes that agreement in patient inversion is 'topic' agreement, rather than subject agreement.

Another aspect of the construction is that it may add emphasis not only on the logical subject but on the action overall (Whiteley and Mganga 1969, Whiteley 1972, Russell $1985):^{6}$
(27) Wimbo
u-ta-imb-a
wa-tu mia.
[Swahili]
11.song SM11-FUT-sing-FV 2-person hundred
'A hundred people will sing the song.'

(Whiteley and Mganga 1969: 113, Russell 1985: 477) 
Russell notes that the sentence implies that it will be 'a special performance'. Whiteley and Mganga (1969) refer to patient inversion as 'counter-experiental' to express that the construction is used in contexts in which the action is remarkable or unusual. Presenting an unexpected new situation is one of the subtypes of theticity mentioned by Sasse (2006). That is, the construction as described by Whiteley and Mganga (1969) does not express a narrow focus or contrast on 'a hundred people' but is used as a thetic statement. With respect to these interpretive possibilities, patient inversion seems to differ from instrument inversion, where, as noted above, an expected action is much preferred.

Another aspect of the construction is related to the verbs taking part in it, and it has been noted that semantic and pragmatic aspects of the construction vary with respect to the lexical semantics of the predicate (Russell 1985, Morimoto 2000, Gibson 2008). While at one end of the spectrum we find verbs with high transitivity and agentivity of the logical subject, as seen in the examples in this section so far, at the other end are verbs with a low distinction between arguments such as $-v a$ 'come out' in (28), where the semantic and pragmatic differences between non-inverted and inverted constructions are less pronounced. ${ }^{7}$

(28) a. Ama-ráso a-va

mu-ru-guma.

[Kirundi]

6-blood SM6-come.out 18-11-wound

'Le sang sort de la blessure.' ('Blood comes out of the wound.') 
b. Uru-guma ru-va ama-ráso.

11-wound SM11-come.out 6-blood

'Le sang sort de la blessure.' (Lit.: 'La blessure sort le sang.') ('The wound oozes blood.')

(Meeussen 1959: 215)

Apart from locatives, instruments and patients, we may wonder whether DPs with other thematic roles can undergo inversion. One possibility might be 'purpose inversion', which at first sight seems to be similar to the inversion constructions discussed so far. The preverbal DP seems to bear a thematic 'purpose' or 'motive' role and is morphologically unmarked. The verb agrees in class with the purpose DP:

(29) a. Baudoin a-rongoye ubu-tunzi. [Kirundi]

1.Baudouin SM1-married 14-wealth

'Baudouin married for wealth.'

b. Ubu-tunzi bu-rongoye Baudoin.

14-wealth SM14-married 1.Baudouin

'It is Baudouin who married (for) wealth.'

(Ferdinand Mberamihigo, p.c. March 2013)

However, this is quite possibly an instance of metonymy, where 'wealth' is a striking property of the person he married. The construction would then be an example of patient inversion, replacing the patient by something associated in meaning. ${ }^{8}$ This analysis is strengthened by the metonymic meaning in examples like (30), and in the impossibility to 
invert sentences which cannot (easily) receive a metaphorical reading such as 'Baudouin ran for glory' (Ferdinand Mberamihigo, p.c.). ${ }^{9}$

\author{
(30) Baudouin y-a-róongoye inzogá. \\ [Kirundi] \\ 1.Baudouin SM1-PST-married 10.beer \\ 'Baudouin has married beer.' = 'Baudouin has married a drunkard.' \\ (Ferdinand Mberamihigo, p.c. September 2013)
}

It remains to be seen whether true purpose inversion is possible or not, which bears on the more general question on the status of the preverbal phrase as an argument or an adjunct (see also section 8.3).

\title{
4.4 Complement inversion
}

Complement inversion differs syntactically slightly from the preceding inversion types, as the initial element can be clausal rather than nominal. However, the construction can be characterised in terms of thematic roles as well - as involving activities, events, or propositions, or (in quotative inversion discussed in the next section) assertions - and so can be seen as constituting a natural extension of the previous types of inversion which we have classified by reference to the thematic roles involved. In complement inversion, the complement of verbs taking clausal complements is coded as subject of the verb. The complement can be either an infinitive (31) or a clause introduced by a complementiser (32): 
(31) a. Aba-ana ba-kuunda gu-kina.

2-children SM2-like 15-play

'The children like to play.'

b. Gu-kina gu-kuunda aba-ana.

15-play SM15-like 2-children

'It is the children who like to play.' (Morimoto 2000: 183)

(32) a. Umu-gore y-iibagiw-e ko aba-ana

1-woman SM1-forget-PRF COMP 2-child

b-a-gii-ye.

SM2-PST-leave-PRF

'The woman forgot that children have left.' (Morimoto 2000: 184)

b. [Ko aba-ana b-a-gii-ye $] \quad$ by-iibagiw-e

COMP 2-children SM2-PST-leave-PRF SM8-forget-PRF

umugore.

1.woman

'It is the woman (not the man) who forgot that children have left.'

(Kimenyi 1980: 193)

Since infinitives in Bantu are part of the noun class system, typically of class 15 (Visser 1989), the verb in (31b) shows class 15 agreement. In contrast, there is no obvious noun class for clauses, and in (32b) the verb shows class 8 default agreement. In both cases, the logical subject follows the verb as in other inversion constructions. ${ }^{10}$ 
It is debatable, however, whether the infinitive in (31) really forms a clause, or should rather be seen as a nominal object (in class 15). One indication that it forms a clause is the fact that default agreement seems generally to be preferred (Jean Paul Ngoboka, p.c.).

(33) Gu-kina bi-kunda aba-na.
15-play SM8-like 2-child
'It is the children who like to play.'

On the other hand, the infinitive does not function as a full clause in all respects: we might expect [VO] clauses to be 'invertable' as well, but the result is marked (Jean-Paul Ngoboka, p.c.):

(34) a. Aba-na ba-kunda ku-rya umu-gati.

2-child SM2-like 15-eat 3-bread

'(The) children like to eat bread.'

b. ?Ku-rya umu-gati bi-kunda aba-na.

15-eat 3-bread SM8-like 2-child

'The children like to eat bread.'

c. *Ku-rya umu-gati gu-kunda aba-na.

15-eat 3-bread SM15-like 2-child

Intd.: 'The children like to eat bread.' 
The data indicate that class 15 infinitives retain their ambivalent nominal/clausal status in inversion constructions, showing either class 15 nominal agreement or class 8 default agreement like true inverted clausal complements - this latter agreement is the only option when an infinitive containing a complement is inverted.

\subsection{Quotative inversion}

Quotative inversion (cf. Güldemann 2008) is very similar to complement inversion with clausal complements. It occurs with verbs of saying taking declarative or interrogative complements, and might be regarded as a sub-case of complement inversion:

(35) Kw-ent-e

njani? ku-buta unina.

[siSwati]

SM17-happen-PRF what? SM17-ask mother.his

'What happened?, asked his mother.' (Ziervogel and Mabuza 1976: 226)

As in clausal complement inversion, there is no appropriate class for the clausal question and so in (35), the verb shows default agreement of class 17, a former locative class (further discussed in section 5 below).

\subsection{Object relatives}

Although we are concentrating on main clause inversion in our study, a short discussion of inversion in relative clauses is in order, to show the similarities between the construction types. Like patient inversion, subject inversion in relative clauses has been well described (Demuth and Harford 1999, Harford and Demuth 1999, Zeller 2004, Henderson 2006, 2011). Overt subjects in object (and other non-subject) relatives may 
precede or follow the verb, as the examples from Sesotho and Shona show (Demuth and Harford 1999):

(36)

\begin{tabular}{|c|c|c|c|}
\hline Se-tulo seo & ba-sadi & ba-se-rek-ile-ng & kajeno ... \\
\hline REL7 & 2-woman & SM2-OM7-buy-PRF-REL & today \\
\hline
\end{tabular}

'The chair which the women bought today ...'

(37)

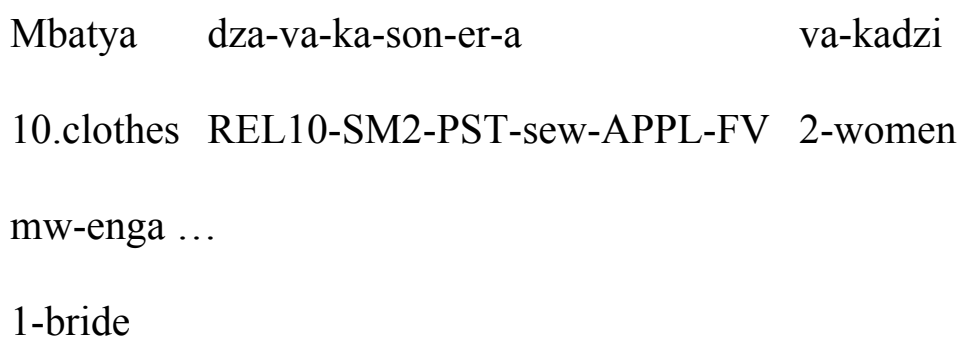

'Clothes which the women sewed for the bride ...'

There is variation between different Bantu languages, and between different relative construction types within single languages, as to whether inversion is optional or obligatory. Obligatory subject inversion is often related to the morphology of the relative marker. Relative constructions in which the relative marker is a bound affix often have obligatory subject inversion (although not always - Zulu, for example, being a counterexample, cf. Henderson 2006, Zeller 2004), while in constructions with a morphologically free and prosodically independent relative marker subject inversion is not required or sometimes not permitted. For example, pronominal relatives in Bemba allow both positions of the subject (38) (e.g. Kula and Cheng 2007), while synthetic relatives in Swahili (39) require subject inversion (e.g. Barrett-Keach 1985, Buell 2002):

(38) a. Abá-ntú ábo Chisanga á-mwééne maílo ...

[Bemba] 
2-person REL2 1.Chisanga SM1-see.PRF yesterday

'The people that Chisanga saw yesterday ...'

b. Abá-ntú ábo á-mwééne Chisanga maílo ...

2-person REL2 SM1-see.PRF 1.Chisanga yesterday

'The people that Chisanga saw yesterday ...'

(39)

a. Ki-tabu a-li-cho-nunu-a Juma ...

[Swahili]

7-book SM1-PST-REL7-buy-FV 1.Juma

'The book which Juma bought ...'

b. *Ki-tabu Juma a-li-cho-nunu-a ...

7-book 1.Juma SM1-PST-REL7-buy-FV

Intd.: 'The book which Juma bought ...'

Henderson (2011) proposes that non-subject relative clause inversion and patient inversion constructions, as shown in the Dzamba examples in (40), are derived by the same underlying mechanism (operator movement to the high left periphery), the difference being whether the operator is a relative feature or a topic feature:

(40) a. Imu-kanda mú-tom-aki omw-ana ...

[Dzamba]

5-letter SM5-send-PRF 1-child

'The letter that the child sent ...' 
b. Imu-kanda mu-tom-aki omw-ana.

5-letter SM5-send-PRF 1-child

'The letter, the child sent it.'

(Henderson 2011: 743)

In this analysis, the similar - though not identical (cf. Henderson 2011: 747) - distribution of patient inversion and relatives with subject inversion is related to the absence of complex left-peripheral structure in languages with inversion in both cases. However, further empirical research is needed to document the relation between relative inversion and patient inversion in detail, and so in what follows we will not discuss relative constructions further, but concentrate on main clause inversion types.

\subsection{Passive}

The final construction we look at in passing are passives. Passives are well described, and in some respects not a typical subject inversion construction. In contrast to the inversion constructions described here, passives are typically formally marked by a verbal passive marker. Often this is a verbal suffix and a reflex of the Proto-Bantu passive marker ${ }^{*}-u$ (Stappers 1967), or a newly developed suffix from e.g. a middle or neutro-passive marker (Schadeberg 2003: 76). In a range of Bantu languages, a new grammaticalised passive marker has developed, based on an erstwhile class 2 subject marker (e.g. Givón 1979, Kawasha 2007, Kula and Marten 2010). In addition, the logical subject in passives is typically expressed by an optional prepositional phrase, and in some Bantu languages, passives allow object markers (Woolford 1995).

However, there are exceptions to these canonical forms. Bostoen and Mundeke (2011) describe a functional passive in Mbuun, which resembles an object topicalisation 
construction, and does not involve passive morphology. In Luganda (Ashton et al. 1954, Pak 2008) and Haya (Duranti and Byarushengo 1977), verbs show passive morphology, but the postverbal agent DP, while being optional, is not coded as an oblique phrase. It is a DP which immediately follows the passive verb, and precedes any other arguments (Pak 2008: 365):

(41)
Omu-kazi y-a-w-ebw'
omu-sajja eki-tabo.
1-woman SM1-PST-give-PASS 1-man 7-book
'The woman was given the book by the man.'

[Luganda]

The morphology and the position of the agent-phrase in (41) is similar to postverbal DPs in inversion constructions, but importantly in inversion constructions, the presence of the postverbal DP is mandatory, not optional.

A second reason for including passives here as distant relations of proper subject inversion constructions is that, like in inversion constructions, focus can fall on the logical subject, as the examples from Sesotho show (Demuth 1989: 68, Demuth and Kline 2006): $:^{11}$
(42) a. Li-jo li-pheh-iloe
ke mang?
[Sesotho]
5-food SM5-cook-PFV.PASS by who
'The food was cooked by who?'
b. Li-pheh-iloe
ke Thabo.
SM5-cook-PFV.PASS by Thabo

'It was cooked by Thabo.' 
Since in Sesotho, the preverbal position is restricted to topics, focused subjects cannot occur in that position, and subject focus is often expressed by default inversion constructions (discussed below) or cleft constructions (Zerbian 2006). However, passives provide an alternative, allowing focused subjects to appear clause-finally, rather than in the canonical topic position.

\subsection{Summary}

The construction types discussed so far illustrate the variety of subject inversion constructions in Bantu. A core of constructions exhibits a high degree of structural and functional similarities, and is mainly distinguished by the thematic role of the non-subject argument promoted to preverbal position. These are formal locative inversion, semantic locative inversion, instrument inversion, patient inversion, and complement inversion (with quotative inversion as a sub-type). We have also shown that subject inversion in non-subject relatives and passive constructions, despite a number of differences, share some aspects of core, main clause subject inversion constructions.

The core properties of core inversion constructions discussed so far are:

1. The logical subject expression is in a postverbal position

2. An expression other than the logical subject expression is in preverbal position and triggers verbal agreement

3. The preverbal expression typically functions as topic, and the postverbal expression is non-topical (often being underspecified as thetic or narrow subject focus)

4. There is a close prosodic bond between the verb and the postverbal expression

5. Object marking is blocked 
Our main criterion for distinguishing the different types of inversion is based on differences in the thematic role of the preverbal DP: locative, instrument, patient, and, for complement inversion, assertion and question. In section 7 , we will look further at the distribution of the constructions across different Bantu languages, and try to chart their occurrence in the family and within individual languages, and any co-occurrence restrictions among them. Before this, we will look at two further construction types default agreement inversion and agreeing inversion - in which there is no agreeing preverbal DP in the next section.

\section{Default agreement inversion and agreeing inversion}

A special kind of subject inversion constructions are those in which the subject appears in postverbal position, but no non-subject is promoted to preverbal position. A typical example of this construction type are presentational constructions in which verbal agreement is non-referential, but there are also inversion constructions in which agreement is with the postverbal subject. We distinguish these two cases as default agreement inversion and agreeing inversion. While inversion constructions with a preverbal non-subject phrase are cross-linguistically relatively rare, these presentational constructions are quite common. Default agreement inversion is found, for example, in Tswana (43), agreeing inversion in Makhuwa (44):

(43) Gó tsàmá-ílé Mphó.

[Tswana]

SM17 go-PRF.CJ Mpho

'There has gone Mpho.' (Creissels 1996: 113) 
(44) Ni-hoó-wá

n-láikha.

[Makhuwa]

SM5-PRF.DJ-come 5-angel

'There came an angel.'

In both examples, the logical subject follows the verb. In (43), the subject agreement is a historical locative marker, which has grammaticalised into a default subject marker. In (44), the subject marker agrees in class with the postverbal subject.

Default agreement is superficially similar to formal locative inversion, which may be a historical source of the default subject marker. However, in contrast to locative inversion, the subject marker in default agreement inversion is not referential, and is used without referring to a particular place (Demuth 1990, Buell 2007, Creissels 2011). When a default agreement construction contains a preposed locative adjunct, the default subject marker fails to show agreement (45), and the locative can be resumed by a locative pronoun such as khona in Zulu (46).
a. Mó kéreké-ng
gó
ópélá ba-sádi.
[Tswana]
LOC 9.church-LOC SM15/17 sing 2-woman

'In the church there are women singing.' (Lit.: 'There sing women.')

(Creissels 2011: 42)

b. Fá-se-tlharé-ng gó-émé ba-símané.

16-7-tree-LOC SM17-stand.PRF 2-boys

'By the tree stand the boys.' (Demuth and Mmusi 1997: 4)

c. Mó-le-fátshé-ng gó-fúla di-kgomo. 
18-5-country-LOC SM17-graze 10-cattle

'In the country are grazing the cattle.' (Demuth and Mmusi 1997: 4)

(46) Ku-le fektri ku-sebenza (khona) izingcweti eziningi.

[Zulu]

17-9.this 9.factory SM17-work there 10.experts 10.many

'Many experts work at this factory.' (Buell 2007: 118)

Examples like these show that the preverbal locative is not a grammatical subject as in locative inversion.

Agreeing inversion is superficially similar to afterthought constructions. In both these constructions, the verb shows agreement with the subject. However, in contrast to agreeing inversion, in afterthought constructions the subject DP is discourse-old and known from the context. Furthermore, it is phrased separately, as can be shown in various formal tests. In Otjiherero, for example, default agreement inversion requires the use of the complement tone pattern, also found on postverbal objects and indicative of a close prosodic relation between the verb and the following DP (47a), while in an afterthought construction, the right-dislocated DP shows default tone pattern (47b).

(47) a. P-è-yá

òvá-éndà.

[Otjiherero]

SM16-PST-come 2CC-visitor

'Visitors came.'/‘There came visitors.'

b. V-è-yá, òvà-éndà.

SM2-PST-come 2DC-visitor

'They came, the visitors.' 
(Marten 2011: 801)

In Northern Sotho, an agreeing subject is also right-dislocated, as can be seen in the use of the disjoint verb form rather than the conjoint, as well as the separate phonological phrasing (the penultimate syllable being lengthened) in (48).

Ó-a-só:ma

mo:-nna.

[Northern Sotho]

1SM-PRES.DJ-work 1-man

'He is working, the man.' (Zerbian 2006: 127)

The verbal agreement marker in these afterthought constructions can be analysed as agreeing with a contextually given discourse topic rather than with the right-dislocated DP directly. We assume that afterthought/right-dislocation constructions such as these are independent of subject inversion constructions, and will not discuss afterthought constructions further here.

While most Bantu languages have either agreeing inversion or default agreement inversion, some Bantu languages, including Lusoga, Kagulu, Swahili, and Tumbuka have both constructions:

(49) a. U-ka-pit-a

mu-da.

[Swahili]

SM3-NAR-pass-FV 3-while

'(And then) a moment passed.'/'There passed a moment.' 
b. Pa-li-pit-a mu-da.

SM16-PST-pass-FV 3-while

'A moment passed.'/'There passed a moment.'

(Marten 2011: 790)

There are no significant syntactic or semantic differences between the two examples in (49), although there are probably differences in terms of their discourse-pragmatic use which require further investigation (cf. Marten 2011: 790/1). Both DAI and AI function to detopicalise the subject, as a result of which the sentence can in many languages be used to either present a whole sentence as new (a thetic sentence) as shown in (50) for DAI in Northern Sotho, or to narrowly focus the postverbal DP, as illustrated in (51) and (52) with an inherently focused wh-word and a DP modified by the focus particle fela 'only'.

Go-be

$$
\text { go-na }
$$

$$
\text { le di-nonyana le }
$$

di-phukubje

[N. Sotho]

SM17-be.PST SM17-be with 10-bird and 10-jackal

tš-eo di-be-go di-dula le-šoke-ng.

10-REL SM10-be.PST-REL SM10-live 5-wilderness-LOC

'There were birds and jackals that lived in the wilderness.' (Beginning of a story)

(Matabane 1998, via Zerbian 2006: 276)

(51) Go-fihl-a

mang?

SM17-arrive-FV who

'Who is arriving?' 
Go-binne basadi fela.

SM17-dance.PST 2-woman only

'Only women danced.' (Zerbian 2006: 70)

The same underspecified non-topical interpretation is found in Matengo agreeing inversion, as suggested by the contexts in which the VS order is judged felicitous:

(53) Gu-hábwiki ńko:ngo.

[Matengo]

3SM-fall.PERF 3.tree

(As a thetic sentence) 'A tree has fallen down.'

(Answer to 'What has fallen down?') 'A tree has fallen down.' (Yoneda 2011:756)

In languages which allow transitive predicates in the construction, the word order is typically VSO, for example in Digo, Gciriku, Kilega, Matengo, Ndebele, Otjiherero and Xhosa.

(54) Pé-rís-à

òvá-éndá òzò-ngòmbé.

[Otjiherero]

SM16.HAB-feed-FV 2CC-guest 10DC-cow

'There feed guests cattle.' (Marten 2006: 115)

[VSO]

(55) ßa-jïmbire ßa-mäti li-dína.

[Dciriku]

SM2-sing.PRF 2-boy 5-song

'The boys had sung a song.' (Möhlig 1967: 242)

[VSO] 
However, in Makhuwa and Kirundi, VOS order is found (56). This is a true inversion construction and not a right-dislocation of the subject, as evidenced by the absence of a prosodic break between object and subject, and the interpretation as a thetic sentence, being uttered out of the blue.

(56) Oo-várá

ephepélé naphúl' úule.

[Makhuwa]

SM1.PRF.DJ-grab 9.fly 1a.frog DEM1

'That frog caught a fly'. (Van der Wal 2009: 197)

[VOS]

Both default agreement inversion and agreeing inversion share with other inversion constructions that the logical subject follows the verb, that the construction is used to express a non-topical reading of the postverbal DP(s), and that typically, in languages which mark the bonding between verb and following DP, the 'strong' bond form (complement tone pattern, conjoint verb form, joint phonological phrasing) is used.

In the following sections we will bring out shared qualities of inversion constructions more directly and adopt a systematic approach for comparing different subject-inversion constructions in Bantu.

\section{Comparing subject inversion constructions}

The comparative approach adopted here has two aspects. First we will develop a systematic framework for comparing the different constructions discussed so far. This will employ a set of variables to identify and distinguish different subject inversion constructions. In the following section we will then compare different Bantu languages to 
chart the distribution of different construction types across the family. The current section addresses the question of whether there is a systematic relation between these different inversion types. Section 7 is then concerned with whether there are systematic relations between languages which allow different inversion types.

Bantu subject inversion constructions can be understood as occupying a typological space characterised by invariant common characteristics and variable features (cf. section 1). The constant characteristics of core subject inversion constructions are:

1. The logical subject follows the verb and cannot be omitted

2. The postverbal subject is non-topical (but often underspecified for narrow subject focus or use as a thetic sentence)

3. Object marking is not possible

4. Close 'bonding' between verb and postverbal DP is often indicated in phonological phrasing, absence of augment, conjoint verb form, or complement tone pattern

Differences between subject inversion constructions come about through differences along a set of variable features:

5. Morphological marking of the preverbal phrase

a. Locative marking

6. Thematic restrictions on the preverbal phrase
a. Locative
b. Instrument
c. Patient
d. Proposition 
7. Agreement
a. Agreement with the preverbal DP/'topic'/clause
b. Default (locative) agreement
c. Agreement with the inverted logical subject

8. Word order
a. VS only
b. VS and VOS
c. VS and VSO

Within this space, we identify nine variables of variation V1-V9 (Table 2). These distinguish the seven subject inversion constructions and passives as a related construction:

○ Formal Locative Inversion (FLI)

- Semantic Locative Inversion (SLI)

○ Instrument Inversion (InsI)

○ Patient Inversion (PatI)

○ Complement Inversion (CmpI)

○ Default Agreement Inversion (DAI)

$\circ \quad$ Agreeing Inversion (AI)

○ Passives (PASS) 


\begin{tabular}{|c|c|c|c|c|c|c|c|c|}
\hline & FLI & SLI & InsI & PatI & $\mathrm{CmpI}$ & DAI & AI & PASS \\
\hline $\begin{array}{l}\text { V1 Verb-logical } \\
\text { subject order }\end{array}$ & $\checkmark$ & $\checkmark$ & $\checkmark$ & $\checkmark$ & $\checkmark$ & $\checkmark$ & $\checkmark$ & $\checkmark$ \\
\hline $\begin{array}{l}\text { V2 Postverbal/ } \\
\text { thetic focus }\end{array}$ & $\checkmark$ & $\checkmark$ & $\checkmark$ & $\checkmark$ & $\checkmark$ & $\checkmark$ & $\checkmark$ & $\checkmark$ \\
\hline $\begin{array}{l}\text { V3 No object } \\
\text { marker }\end{array}$ & $\checkmark$ & $\checkmark$ & $\checkmark$ & $\checkmark$ & $\checkmark$ & $\checkmark$ & $\checkmark$ & $(\checkmark)$ \\
\hline $\begin{array}{l}\text { V4 Logical } \\
\text { subject cannot } \\
\text { be omitted }\end{array}$ & $\checkmark$ & $\checkmark$ & $\checkmark$ & $\checkmark$ & $\checkmark$ & $\checkmark$ & $\checkmark$ & $x$ \\
\hline $\begin{array}{l}\text { V5 Close bond } \\
\text { between V and } \\
\text { S }\end{array}$ & $\checkmark$ & $\checkmark$ & $\checkmark$ & $\checkmark$ & $\checkmark$ & $\checkmark$ & $\checkmark$ & $x$ \\
\hline $\begin{array}{l}\text { V6 Overt/ } \\
\text { referential topic }\end{array}$ & $\checkmark$ & $\checkmark$ & $\checkmark$ & $\checkmark$ & $\checkmark$ & $x$ & $x$ & $x$ \\
\hline $\begin{array}{l}\text { V7 Thematic } \\
\text { restrictions on } \\
\text { preverbal } \\
\text { element }\end{array}$ & $\begin{array}{c}\checkmark \\
\text { LOC }\end{array}$ & $\begin{array}{c}\checkmark \\
\text { LOC }\end{array}$ & $\begin{array}{c}\checkmark \\
\text { INS }\end{array}$ & $\begin{array}{c}\checkmark \\
\text { TH }\end{array}$ & $\begin{array}{c}\checkmark \\
\text { PRO }\end{array}$ & $x$ & $x$ & $x$ \\
\hline $\begin{array}{l}\text { V8 } \\
\text { Morphological } \\
\text { marking of pre- } \\
\text { verbal phrase }\end{array}$ & $\checkmark$ & $x$ & $x$ & $x$ & $x$ & $x$ & $x$ & $x$ \\
\hline $\begin{array}{l}\text { V9 Agreement } \\
\text { with logical } \\
\text { subject }\end{array}$ & $x$ & $x$ & $x$ & $x$ & $x$ & $x$ & $\checkmark$ & $x$ \\
\hline
\end{tabular}

Table 2: Variables V1 to V9 for Bantu subject inversion constructions

The nine variables identify a broad group of subject inversion constructions, including passives, as a group of related constructions with a set of shared parameters (V1-V3). A central group is defined by V4 and V5 which excludes passives, where the logical subject can be omitted and where there is no close bond between verb and the following logical subject. V6 sets apart Default Agreement Inversion and Agreeing Inversion from the five other inversion constructions since in the former there is no referential topic. V7 shows that the five inversion constructions with referential topics (FLI, SLI, InsI, PatI, and 
$\mathrm{CmpI}$ ), which can be regarded as core group, are only distinguished by their different thematic restrictions. V8 sets Formal Locative Inversion apart from other inversion constructions, due to the overt morphological marking of the locative topic. This is the only difference between Formal Locative Inversion and Semantic Locative Inversion. Finally, V9 singles out Agreeing Inversion (and distinguishes it from Default Agreement Inversion) as the only construction showing agreement with the logical subject.

Taken together, the nine variables in Table 2 provide an overall characterisation of the set of subject inversion constructions in Bantu, and distinguish between the seven inversion constructions (and passives as a more peripheral construction). In the next section, we will compare the distribution of inversion construction types across a selected set of Bantu languages.

\section{Subject inversion constructions across a sample of Bantu languages}

Our comparative study of the seven core inversion constructions is based on a convenience sample of 46 Bantu languages. Information about inversion constructions was mainly collected from published sources. ${ }^{12}$ In addition, for some languages information was collected through questionnaires (a sample questionnaire is included in the appendix). Unfortunately, for many languages, our knowledge is incomplete, and a large amount of descriptive work remains to be carried out. Languages were selected mainly based on the information available, and so the sample is not balanced or representative. In terms of geographical spread, we have included data from thirteen of Guthrie's (1967-71) fifteen zones: Languages from zones $\mathrm{F}$ and $\mathrm{H}$ are missing. Furthermore, zones are not represented evenly. While for some zones, only one language is part of the sample, for others several languages are included. In particular Zone $\mathrm{S}$ is strongly over-represented, with nine of the 46 languages, reflecting the comparatively 
good availability of sources for the syntax of southern African Bantu languages. Table 3 provides a summary of our findings. Languages are arranged by zone, broadly moving from northwest to southeast. Presence of a construction type is coded as ' 1 ', absence as ' 0 '. 'Cop' means that the construction is present, but only available with a copula as predicate. ${ }^{13}$ An empty cell means that we do not have the relevant information. For convenience affirmative cells are highlighted in bold. 


\begin{tabular}{|c|c|c|c|c|c|c|c|c|}
\hline & & 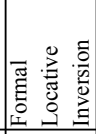 & 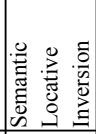 & 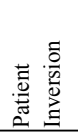 & 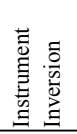 & 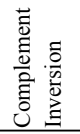 & 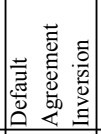 & 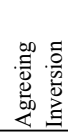 \\
\hline A43a & Basaa & 0 & 0 & 0 & 0 & 0 & 0 & 0 \\
\hline B865 & Nzadi & 1 & & 1 & 0 & & & \\
\hline B87 & Mbuun & 0 & 0 & 0 & 0 & 0 & 0 & 0 \\
\hline C322 & Dzamba & 1 & & 1 & & & & \\
\hline D25 & Kilega & $1 ?$ & & 1 & & & 1 & \\
\hline D54 & Bembe & cop & & & & & 1 & \\
\hline E51 & Gikuyu & & & & & & cop & \\
\hline E54 & Kîtharaka & 0 & 1 & 0 & 0 & 0 & 1 & cop \\
\hline E62 & Chaga & 1 & & & & & & \\
\hline E73 & Digo & 1 & & & & & & \\
\hline G12 & Kagulu & 1 & & 1 & & & cop & 1 \\
\hline G35 & Luguru & & & 1 & & & & 1 \\
\hline G402 & Makwe & 1 & & & & & & 1 \\
\hline G42 & Swahili & 1 & 1 & 0 & 0 & 0 & 1 & 1 \\
\hline G52 & Chindamba & 1 & & & & & & \\
\hline JD42 & Kinande & 1 & & 1 & & & 1 & 0 \\
\hline JD61 & Kinyarwanda & 0 & $1 ?$ & 1 & & 1 & & \\
\hline JD62 & Kirundi & 0 & $1 ?$ & 1 & 1 & & 1 & \\
\hline JD63 & Kifuliiru & 1 & & & & & cop? & \\
\hline JE16 & Lusoga & 1 & & 1 & 1 & 0 & 1 & 1 \\
\hline JE31 & Lubukusu & 1 & & & & & 0 & 1 \\
\hline$J E 32 b$ & Olutsootso & cop & 1 & & & & & \\
\hline K21 & Lozi & 0 & & & & & 1 & \\
\hline K332 & Dciriku & cop? & & 0 & & & cop & 1 \\
\hline L31 & Ciluba & cop & & & & & & \\
\hline M42 & Bemba & 1 & 0 & 0 & 0 & 0 & cop & 1 \\
\hline N101 & Kindendeule & 1 & & & & & & \\
\hline N122 & Moz Ngoni & & & & & & & 1 \\
\hline N13 & Matengo & 0 & 0 & 0 & 0 & & 0 & 1 \\
\hline $\mathrm{N} 21$ & Tumbuka & 1 & & 0 & $1 ?$ & & 1 & 1 \\
\hline N31 & Chichewa & 1 & 0 & 0 & & & & 0 \\
\hline N41 & Nsenga & 1 & & & & & & 1 \\
\hline P13 & Kimatuumbi & 0 & 0 & 0 & 0 & & 0 & 1 \\
\hline $\mathrm{P} 22$ & Yao & 1 & & 1 & & & & \\
\hline P31 & Makhuwa & 0 & 0 & 0 & 0 & & 0 & 1 \\
\hline P311 & Ekoti & & & & & & & 1 \\
\hline R31 & Otjiherero & 1 & 0 & 0 & & & 1 & 0 \\
\hline S10 & Shona & 1 & & & & & 1 & \\
\hline S31 & Tswana & 0 & & 0 & 0 & & 1 & 0 \\
\hline $\mathrm{S} 32$ & Sesotho & 0 & 0 & 0 & 0 & & 1 & 0 \\
\hline S33 & N. Sotho & 0 & 0 & 0 & 0 & & 1 & 0 \\
\hline S41 & Xhosa & & 1 & & & & 1 & \\
\hline S42 & Zulu & 0 & 1 & 0 & 1 & & 1 & 0 \\
\hline S43 & Swati & 0 & 1 & & 1 & & 1 & \\
\hline S44 & Ndebele & 0 & 1 & 0 & 1 & 0 & 1 & 0 \\
\hline S53 & Tsonga/Changana & 0 & & 0 & & & 1 & \\
\hline
\end{tabular}

Table 3: Inversion constructions in 46 Bantu languages

The data in Table 3 provide an overview of the distribution of different inversion constructions. In terms of the overall pattern, the different constructions show some 
differences. Formal locative inversion seems widespread throughout the sample, although it is not found in the southeastern S languages, Makhuwa, or in Lozi which is historically closely related to Sotho-Tswana (Gowlett 1989). Janson's (1991/1992) proposal that Makhuwa and Sotho were historically connected and then separated by languages of zone $\mathrm{N}$ would explain that Makhuwa patterns with this group.

Semantic locative inversion is found in the northeast and in Nguni languages, and is less well represented in the central and south-central areas. Patient inversion is mainly found in the northeast, but also in Dzamba, Kilega, Nzadi and Yao. There are few data for instrument inversion, which is found in the two Nguni languages Zulu and siSwati, as well as in Kirundi and possibly in Tumbuka. For complement inversion we only have data from five languages, so it is difficult to draw any conclusions about distribution. Default agreement inversion is widespread, but is often restricted to copulas. Agreeing inversion is widespread except in the southeast.

Some observations can also be made about the co-occurrence of different construction types. There seems to be considerable complementarity between formal locative inversion and semantic locative inversion. Most languages have either one or the other, although, as noted already above, some languages have both. In the sample, these are Olutsootso and Swahili. As we will discuss in more detail below, the presence of semantic locative inversion could be seen as being related to the loss of locative DPs - a change which was widespread in southern Bantu. However, from this perspective, the presence of both formal and semantic locative inversion in one language is unexpected (see further section 8.1), and so further research on these languages is needed. It is noteworthy, however, that in Olutsootso formal locative inversion, though not semantic locative inversion, is restricted to copulas. The case for Swahili requires more detailed investigation, but it might well be related to the loss of productive nominal locative morphology - as in 
Swahili the historical locative prefixes have been replaced by the invariant locative suffix $-n i-$ and consequent ambiguity as to whether locatives are treated as DP or PP. This, in addition to contact influence in the case of second language speakers, might result in a high degree of dialectal or inter-speaker variation resulting in the impression that both formal and semantic locative inversion are possible. However, more work on Swahili syntactic variation is necessary to develop this argument in detail.

Some unidirectional implicational relations appear in the data, even though often based on a small number of languages: For example, all languages with instrument inversion also have (formal or semantic) locative inversion, as do all languages with patient inversion. There are not enough data to compare co-occurrence of patient and instrument inversion, or the relation of complement inversion with other construction types. For default agreement inversion and agreeing inversion, all patterns of co-occurrence are attested, with the majority of languages having at least one of these constructions, and several having both.

In terms of constructions available in a given language, Lusoga, Swahili and Kirundi are the languages with most construction types; five are found in Lusoga and four in Swahili and possibly also in Kirundi. Judgements for Swahili vary in the literature, in particular with respect to patient inversion, and it might be better to distinguish different varieties of Swahili in future work. The data here reflect our own work and judgements from southern coastal Swahili. On the other end of the spectrum, Matengo and TswanaSotho have only one of the construction types - Matengo has only agreeing inversion, Tswana, Sesotho and Northern Sotho have only default agreement inversion - and Basaa and Mbuun, both in the northwest of the Bantu area, do not have any inversion construction at all. 
Despite the gaps in the data, some quantitative observations can be made. Taking into account only those languages for which we have information about a given construction, Table 4 shows the relative presence or absence of the construction. For example, of the 41 languages for which we have information about formal locative inversion, 25 (61\%) have the construction, $16(39 \%)$ do not. The bottom row shows the number of languages for which we do not have relevant information, so, for example, for five languages, we have no information about whether they have formal locative inversion. .

\begin{tabular}{|c|c|c|c|c|c|c|c|}
\hline & 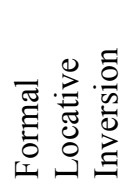 & 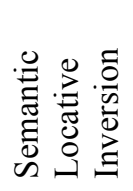 & 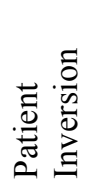 & 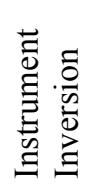 & 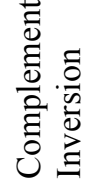 & 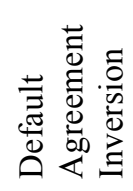 & 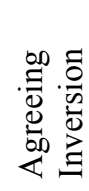 \\
\hline $\begin{array}{l}\text { Languages } \\
\text { with data } \\
\text { (n) }\end{array}$ & 41 & 19 & 28 & 18 & 9 & 30 & 26 \\
\hline Yes $(n / \%)$ & $\begin{array}{c}25 \\
61 \%\end{array}$ & $\begin{array}{c}9 \\
47 \%\end{array}$ & $\begin{array}{c}10 \\
36 \%\end{array}$ & $\begin{array}{c}6 \\
33 \%\end{array}$ & $\begin{array}{c}2 \\
22 \%\end{array}$ & $\begin{array}{c}24 \\
77 \%\end{array}$ & $\begin{array}{c}16 \\
62 \%\end{array}$ \\
\hline No $(\mathrm{n} / \%)$ & $\begin{array}{c}16 \\
39 \%\end{array}$ & $\begin{array}{c}10 \\
53 \%\end{array}$ & $\begin{array}{c}18 \\
64 \%\end{array}$ & $\begin{array}{c}12 \\
67 \%\end{array}$ & $\begin{array}{c}7 \\
78 \%\end{array}$ & $\begin{array}{c}6 \\
19 \%\end{array}$ & $\begin{array}{c}10 \\
38 \%\end{array}$ \\
\hline $\begin{array}{l}\text { Languages } \\
\text { without } \\
\text { data (n) }\end{array}$ & 5 & 27 & 18 & 28 & 37 & 16 & 20 \\
\hline
\end{tabular}

Table 4: Distribution of inversion constructions in the sample (based on 46 languages in total)

The results in Table 4 are sometimes based on very low numbers, and so further research is likely to change the picture. However, from the data available, we see that the majority of languages have formal locative inversion, default agreement inversion and agreeing inversion. In contrast, the majority of languages do not have instrument inversion, patient 
inversion and complement inversion. For semantic locative inversion, the situation is fairly balanced: about half the relevant languages have the construction, the other half do not. The languages most closely reflecting these overall typological tendencies are Bemba and Swahili (Table 5), which have formal locative inversion, default agreement inversion, and agreeing inversion. Swahili also has semantic locative inversion, while Bemba does not.

\begin{tabular}{|l|l|l|l|l|l|l|l|l|}
\hline M42 & Bemba & 1 & 0 & 0 & 0 & 0 & cop & 1 \\
\hline G42 & Swahili & 1 & 1 & 0 & 0 & 0 & 1 & 1 \\
\hline
\end{tabular}

Table 5: Inversion constructions in Bemba and Swahili

Similar results are obtained with a slightly different approach to comparing the languages of the sample. In Table (6) we compare the distribution of the constructions in a selected set of 20 languages of the sample with inversion constructions (that is, excluding Basaa and Mbuun) for which we have four or more clear data points.

\begin{tabular}{|l|c|c|c|c|c|c|c|}
\hline & FLI & SLI & PatI & InsI & CompI & DAI & AI \\
\hline $\mathrm{n}=20$ & 8 & 4 & 5 & 3 & 1 & 6 & 8 \\
\hline Percentage of all with 4 data points & $40 \%$ & $20 \%$ & $25 \%$ & $15 \%$ & $5 \%$ & $30 \%$ & $40 \%$ \\
\hline Percentage of valued cells & $50 \%$ & $33 \%$ & $25 \%$ & $23 \%$ & $17 \%$ & $38 \%$ & $50 \%$ \\
\hline
\end{tabular}

Table 6: Distribution of inversion constructions across the sample for languages with 4 or more clear data points (20 languages)

In this smaller sample, formal locative inversion and agreeing inversion are the most frequent constructions, followed by default agreement inversion. These are the same three 
constructions which were present in a majority of languages in the data in Table 4. Quantitative data looked at in different ways thus shows a similar distribution of inversion constructions across the sample of Bantu languages, with formal locative inversion, default agreement inversion and agreeing inversion the most frequent constructions although as noted before, it has to be kept in mind that these findings are based on a very small data sample and are thus no more than indicative. More data from a wider range of languages, and more complete data from most of the languages of our sample are needed to see whether this distribution holds across a wider data set. In the meantime, we will discuss some theoretical implications of our comparative analysis in the following section.

\section{Discussion}

In the discussion so far, we have laid out the variation encountered in subject inversion constructions in Bantu, and charted the distribution of different construction types across our sample of Bantu languages. Our aims have been both descriptive and comparative: Providing a detailed description of different subject inversion constructions, and demonstrating the high degree of morphosyntactic micro-variation encountered in Bantu inversion. However, one of the challenges posed by the kind of micro-variation found in Bantu subject inversions is whether the surface variation can be reduced to more abstract underlying parameters which explain clusters of related properties (Kayne 2005, Baker 2010). While we have not found any clear parametric effects, in this section we discuss four grammatical properties of Bantu languages which we believe play an important role in understanding how variation in subject inversion constructions arises. These are differences in the grammatical status of locatives, differences in the subject agreement 
system, syntactic restrictions on the DPs taking part in inversion, and thematic restrictions on arguments and predicates in inversion constructions.

\subsection{The status of locative phrases as nominal or prepositional}

The morphosyntactic status of locatives in Bantu is subject to some variation, often probably reflecting historical processes of language change. A particular development is the 'Great siSwati Locative Shift' in which locative classes have been reanalysed as prepositional, and so locative phrases function as PPs, not as DPs (Marten 2010).

If locative inversion constructions only take fronted locative DPs (not PPs, as these cannot trigger agreement), we may expect languages that underwent the Great Locative Shift to only have semantic locative inversion. That is, only locative DPs, whether marked with class 16/17/18 morphology (formal locative inversion) or not (semantic locative inversion), participate in locative inversion, effectively making semantic and formal locative inversion the same type. The variation would now be attributed not to the construction itself, but to the cross-linguistic variation in the status of morphologically locative-marked nominal phrases as DPs or PPs. This, in turn, would predict a complementary distribution between formal and semantic locative inversion.

In our sample, there is indeed an overall complementarity between formal and semantic locative inversion. As noted above, languages without locative DPs, such as the Nguni languages siSwati and Zulu, tend to have semantic locative inversion (Buell 2007), and/or default agreement inversion with a preposed locative adjunct (Demuth 1990, Creissels 2011) (see Section 5, above). However, there are exceptions in the form of languages which have both locative inversion types, and a closer look at these exceptional languages will show whether there is a correlation with differences in the locative 
systems. For example, it is possible that the relevant languages are in diachronic flux and in between the two systems, as noted above for Swahili.

An interesting related question, pointed out to us by an anonymous reviewer, is what accounts for the fact that locatives in Zulu require a locative preposition $(k u-)$ when they appear in the "uninverted" postverbal position (57).

a. Abantu abadala bahlala *(ku)-lezi zindlu.

[Zulu]

2.people 2.old 2SM-stay LOC-10.DEM 10.houses

'Old people live in these houses.'

b. $(* \mathrm{Ku})-$ lezi zindlu zi-hlala abantu abadala.

LOC-10.DEM 10.houses 10SM-stay 2.people 2.old

'Old people live in these houses.'

(Halpert 2012: 231)

This, together with the restriction of semantic locative inversion in Zulu, motivated Zeller's (2013) analysis, which claims that the locative in SLI originates in a different position (a predication phrase above the verb phrase). If SLI and FLI differ in this respect, and are structurally distinct, it would be possible for them to co-occur in a single language, but this does not seem to be strongly supported by our data. The largely complementary distribution of SLI and FLI in our data would rather indicate that Zeller's (2013) analysis might apply to both SLI and FLI. However, this proposal and its crosslinguistic validity needs further investigation.

\subsection{Agreement parameter and pronominal status of subject marker}


A lot of literature has addressed the question of agreement in Bantu, and the status of agreement and agreement markers has implications for the analysis of subject inversion constructions. One of the questions is whether subject agreement is structurally determined and whether subject agreement in Bantu is always with a structurally higher and possibly preverbal - element or not (Baker 2003, 2008, Collins 2004, Carstens 2005, Van der Wal 2008, 2012, Diercks 2011, Henderson 2011, Halpert 2012). The widespread existence of agreeing inversion seems to argue against a parameter setting 'upwards agreement' for the whole language family, although detailed study of individual systems is needed to confirm whether the postverbal subject is in a lower position in agreeing inversion. One of the diagnostics here is whether inversion with a transitive predicate takes VSO or VOS order - another point of variation.

A related discussion concerns the status of the subject marker. It is often claimed that subject markers in most Bantu languages can function as a (incorporated) pronoun/clitic with DPs being dislocated topics, or as an agreement marker - the DP being the true argument of the verb, i.e. the grammatical subject (Bresnan and Mchombo 1987, Demuth and Johnson 1989, Morimoto 2000, van der Wal 2008, Marten 2011, Iorio in progress). This might be related to restrictions on the interpretation of pronominal elements more widely, for example, whether subject markers in a given language allow cataphoric reference or expletive interpretations.

This in turn relates directly to the question whether there exist both (and a difference between) subject and topic agreement (Morimoto 2006). The variation found in our sample of Bantu languages attests to the on-going grammaticalisation process whereby topics accompanied by pronominal agreement ('the man, he goes') are reanalysed as subjects and grammatical agreement ('the man he.goes'), as noted by Givón (1976), cf. Ariel (2000). 
A number of recent papers have specifically addressed the question of whether subject agreement is related to (abstract) Case, whether Case is parameterised, and whether Bantu languages have Case at all (Diercks 2012, Carstens and Mletshe to appear, Halpert to appear, van der Wal submitted). If subject agreement were a reflex of Case valuation, we would expect agreement to always be with the nominative subject. That is, no other inversion construction could co-exist with agreeing inversion. Our overview shows that this is only the case in a limited number of languages (Matengo, Ngoni, Matuumbi, Makhuwa, possibly Dciriku). ${ }^{14}$ There are also languages that have agreeing inversion in addition to one or more other inversion constructions (e.g. Swahili, Kagulu, Lubukusu, Bemba), which implies that subject agreement in these languages is not related to Case, but must have some other motivation.

\subsection{Restrictions on the grammatical status of the preverbal phrase in inversion}

constructions

The (original, pre-inversion) grammatical status of the preverbal expression may be expected to place restrictions on subject inversion constructions. On the one hand, locatives and instruments are typically syntactic adjuncts (although see Riedel and Marten 2012 on the ambiguous status of locatives in this respect), and so we would expect them to pattern together, other things being equal. On the other hand, patients and complement clauses are complements, and so we would expect them to pattern together, too. While it is the case that all languages in our sample with instrument inversion have (one kind of) locative inversion, the reverse does not hold. This may in part reflect the different status of locatives as arguments or adjuncts in languages that do not allow instrument inversion. However, it might be profitable to test other adjuncts in inversion constructions, such as purpose/reason clauses or even adverbs as in 'tomorrow travels the children' - the latter 
has not been reported to be possible in any language. If adverbs are DPs and if inversion is about topicality rather than role reversal, there is no obvious reason why temporal adverbs like 'last year' or 'today' would not be allowed as preverbal DP in an inversion construction. This is especially so if the proposals by Zeller $(2012,2013)$ are taken seriously: as mentioned above, he suggests that instruments and semantic locatives in II and SLI originate in a different position, where they are semantically interpreted as the 'holder' of the state denoted by the predicate. For example, in an SLI construction like 'the garden grows grass' the predicate would be 'grass-growing', and the DP 'garden' "denotes an entity of which this situation is predicated as a property" (Zeller 2013: 1111). In the same way, we can imagine a property 'children playing' being predicated of 'today'. This has not been studied and remains an open question.

A related question is the role of applicative marking in inversion. While there is no clear picture, the requirement for applicative marking in some inversion constructions has been noted, for example in some (typically transitive) locative inversion constructions in Otjiherero (Marten 2006), which may indicate that in some circumstances locatives need to be promoted to argument status in order to take part in inversion constructions. However, in general, inversion is independent of applicatives. It seems that locatives and instruments can become subjects in inversion constructions without overt valency change, while this is often not the case for promotion to object, where applicative morphology is typically required. In this context, it might also be interesting to investigate any correlation between the availability of locative and instrument inversion constructions in a given language and the availability of locative and instrument applicatives. A better understanding of the interaction between applicatives and different inversion types is needed to address these questions. 
In addition, as noted above, the categorial difference between DPs such as locatives, instruments and patients, and clauses, such as assertions and quotations, might play a role for participation in inversion. This difference is also connected to the discussion on abstract Case, as DPs are said to require Case, whereas CPs do not (but see Halpert 2012).

\subsection{Thematic restrictions on the preverbal phrase in inversion constructions}

We have already noted that thematic restrictions on the preverbal expression in subjectinversion constructions were central for our categorisation of the data. The reasons for this choice were in part related to the distribution of the construction, since the thematic classification captures the comparative distribution of the Bantu inversion constructions in our sample. Taking into account the frequency and the co-occurrence restrictions of the constructions in our sample, we can propose the following thematic hierarchy of subject inversion constructions:

(58) assertion, quotation $>$ patient/theme $>$ instrument $>$ locative

The first two roles in (58), assertion and quotation, ${ }^{15}$ may be misplaced, as these are grammatically expressed by clauses rather than DPs, and so different constraints might be at work (see 8.3, above). The other three roles, patient, instrument, and locative, are ranked by decreasing topic-worthiness (Givón 1979, Hopper and Thompson 1980, Lambrecht 1994). This supports the view that the lower on the thematic hierarchy a DP is, the easier it is to use it as preverbal DP in subject inversion constructions. For example, locatives, which are low on the hierarchy, make for better inversions than patients. This may seem counterintuitive, but should be understood in the light of its interaction with the subject. Since subjects are typically agents, which are high on this scale, we understand 
that subject inversion is easier the greater the difference in topic-worthiness is between the two arguments.

Further evidence for the ranking in (58) might come from diachronic considerations, where there is some evidence that more liberal systems are replaced by more restrictive systems, along the hierarchy in (58). Zeller (p.c.) reports on the loss of patient inversion in Zulu - which has instrument and semantic locative inversion - and Meeussen (1967) reconstructs patient inversion for Proto-Bantu.

It is also of interest that thematic hierarchies have been argued to play a role in other aspects of Bantu grammar, for example in applicatives (Ngonyani and Ngithinji 2006) and restrictions on predicates taking part in locative inversion (Marten 2006, Khumalo 2010) (see 8.5, below). Bresnan and Kanerva (1989: 23) propose the following hierarchy as relevant for locative inversion in Chichewa:

(59) agent $>$ beneficiary $>$ goal/recipient/experiencer $>$ instrument $>$ patient/ theme $>$ locative

A slightly different version is proposed in Hawkinson and Hyman (1974: 159) and Trithart (1977: 21) (cf. Wald 1997 for discussion), in which instrument and patient/theme are ranked differently:

(60) agent $>$ beneficiary $>$ goal/recipient/experiencer $>$ patient/theme $>$ instrument $>$ locative

This latter hierarchy corresponds well to our proposal in (58) in terms of the ranking of locative, instrument, and patient/theme. 
A noticeable absence in (58) are benefactives which do not seem to participate in inversion constructions. In part this might be due to thematic reasons: benefactives are typically animate and high in topicworthiness, and so do not provide a good contrast to agents. Morphosyntactically, benefactives differ from locatives and instruments in that in non-inversion contexts, the latter can be coded as arguments or adjuncts of the verb, but benefactives can typically only be coded as arguments (through applicative morphology), suggesting that the absence of benefactives in inversion constructions might be related to their invariant argument status. It is interesting in this context to recall that in instrument inversion, the instrument is an expected part of the event, whereas in patient inversion, the event is often portrayed as unexpected. Further work is needed to uncover the relation between argument status and interpretation which seems to be at work here.

Another factor relevant for the absence of benefactive inversion might be related to information structure. Benefactives are typically licensed by applicatives, and applicatives typically introduce focussed rather than topical arguments (Marten 2003, Voisin 2006). However, the pre-posed DP in subject-inversion constructions is topical (and the logical subject non-topical), which means that there might be some tension between benefactives as being more easily correlated with focus, and the information structure in inversion constructions which would require them to be topical.

\subsection{Thematic/lexical restrictions on (the transitivity of) the predicate}

A final parameter of variation in subject inversion constructions is related to lexical or thematic restrictions on the predicate of the inversion construction. Restrictions on predicates have been extensively discussed with respect to variation in formal locative inversion, where it has been argued that different languages allow different predicate types to take part in the inversion (Demuth and Mmusi 1997, Marten 2006, Khumalo 
2010). Similarly, with respect to patient inversion (subject-object reversal) Whiteley and Mganga (1969) and Russell (1985) provide a catalogue of predicates available in the construction, and Gibson (2008) describes different semantic constraints on participating predicates in terms of container and contained image schemas. The transitivity restrictions which appear to play an important part in variation of inversion constructions give rise to a specific implicational hierarchy of predicate types:

(61) copula $>$ unaccusatives $>$ unergatives $>$ transitives $>$ multitransitives ( $>$ 'say'-type verbs)

The middle part of the hierarchy in (61) is reminiscent of those proposed for formal locative inversion, and the two endpoints provide a more fine-grained distinction between copulas and intransitive verbs on the one hand, and (multi)transitive verbs and those taking clausal complements on the other. Both distinctions are necessary for explaining variation in our data. Especially (though not exclusively) default agreement inversion is often restricted to copulas, and complement inversion is often different from patient inversion.

\section{Conclusions}

In this paper we have presented results from a comparative study of Bantu subject inversion constructions. We have distinguished seven construction types and shown their common characteristics and the differences between them. Based on a sample of 46 languages, we have charted the distribution of subject inversion constructions in Bantu and drawn geographic and typological generalisations. Finally we have discussed the 
variation and distribution of subject inversion constructions in the context of wider theoretical and typological aspects of Bantu morphosyntax.

Throughout the discussion we have noted the need for more descriptive work, and the absence of comprehensive data for a number of languages. The results presented here are thus preliminary, and represent on-going work rather than a complete and definite picture. In addition to further descriptive work on inversion constructions, we have also noted the need to further investigate the interaction of inversion constructions with other aspects of Bantu grammar, for example applicative or middle constructions.

Nevertheless, the comparative approach we have adopted shows typological tendencies and implicational relationships between the presence of different construction types, and how results can be used to test hypotheses about underlying structural reasons which account for the observed variation through the interaction of parameters. Results also feed into wider theoretical discussion about the syntax of Bantu inversion constructions, the coding of logical subjects vis-à-vis word order effects, and cross-linguistic microvariation. Above all, the study has shown the high diversity and extensive degree of variation in this aspect of Bantu morphosyntax.

\section{Acknowledgements}

Lutz Marten's part of this research has benefitted from a British Academy UK-Africa Academic Partnership Scheme grant for 'Language and Linguistic Studies of Southern African Languages', and Jenneke van der Wal's part is funded by the European Research Council Advanced Grant No. 269752 'Rethinking Comparative Syntax', both of which are hereby gratefully acknowledged. Earlier version of this paper were presented to audiences at Durban, Lyon, Manchester, Paris, SOAS, and Surrey and we are grateful for 
helpful comments and suggestions received on these occasions as well as from Oliver Bond, Leston Buell, Thilo Schadeberg, Oliver Stegen, Jochen Zeller and two anonymous referees. For information about specific languages we are grateful to Leston Buell (Zulu), Jean Chavula (Tumbuka), Denis Creissels (Tswana), Maud Devos (Makwe and Shangaci), Yussuf Hamad (Swahili), David Iorio (Bembe), Langa Khumalo (Ndebele), Ahmed Kipacha (Swahili), Heidrun Kröger (Mozambican Ngoni), Nancy Kula (Bemba), Michael Marlo (Tiriki), Ferdinand Mberamihigo (Kirundi), Peter Muriungi (Kîitharaka), Minah Nabirye (Lusoga), Jean Paul Ngoboka (Kinyarwanda), Steve Nicolle (Digo), Malin Petzell (Kagulu), Eva-Marie Ström (Ndengereko), Nobuko Yoneda (Matengo), and Jochen Zeller (Zulu). All mistakes and shortcomings remain our own.

\section{Abbreviations of inversion construction types}

$\begin{array}{llll}\text { AI } & \text { Agreeing inversion } & \text { s-V S } & \text { 'she-fell Asha' } \\ \text { CmpI } & \text { Complement inversion } & \text { CP ?-V S } & \text { '[that Sue left] it-forgot Mary' } \\ \text { DAI } & \text { Default agreement inversion } & \text { default-V S } & \text { 'there-fell Asha' } \\ \text { InsI } & \text { Instrument inversion } & \text { inst-DP inst-V S 'with-pen with-write John' } \\ \text { LI } & \text { Locative inversion } & \text { loc-DP loc-V S } & \text { 'in-forest in-fell tree' } \\ \text { PatI } & \text { Patient inversion } & \text { O o-V S } & \text { 'milk it-drank children' }\end{array}$

\section{Main data sources}

Basaa (Hamlaoui and Makasso 2013), Bemba (Nancy Kula p.c.), Bembe (David Iorio p.c.), Chaga (Moshi 1995), Chichewa (Mchombo 2004, Morimoto 2006), Chindamba (Edelsten and Lijongwa 2010), Ciluba (de Kind and Bostoen 2012), Dciriku (Möhlig 1967), Digo (Nicolle 2013), Dzamba (Bokamba 1976), Ekoti (Schadeberg and Mucanheia 2000), Gikuyu (Mugane 1997), Kagulu (Petzell 2008), Kifuliiru (Van Otterloo 2011), 
Kîitharaka (Buell and Muriungi ms., Muriungi 2008), Kilega (Botne 2003), Kimatuumbi (Odden 1984, 1996), Kinande (Baker 2003), Kindendeule (Ngonyani 1996), Kinyarwanda (Kimenyi 1980, Morimoto 2000), Kirundi (Ferdinand Mberamihigo p.c., Ndayiragije 1999), Lozi (Kashina 2005), Lubukusu (Diercks 2010, 2011), Luguru (Marten and Ramadhani 2001, Mkude 1974), Lusoga (Minah Nabirye p.c.), Makhuwa (van der Wal corpus), Makwe (Devos 2004), Matengo (Yoneda 2008, 2011), Mbuun (Bostoen and Mundeke 2011, 2012), Mozambican Ngoni (Heidrun Kröger p.c.), Ndebele (Khumalo 2010, p.c.), Northern Sotho (Zerbian 2006), Nsenga (Marten et al. 2007), Nzadi (Crane, Hyman, Tukumu 2011), Olutsootso (Dalgish 1976), Otjiherero (Marten 2006, Möhlig \& Kavari 2008), Sesotho (Demuth 1990), Shona (Fortune 1955, Harford 1990, Perez 1983), siSwati (Thwala 2006), Swahili (Abdulaziz 1996, Yussuf Hamad p.c., Ahmed Kipacha p.c., Whiteley 1972), Tsonga/Changana (Bonfim Duarte 2011, Zerbian ms.), Tswana (Creissels 2004, 2011, p.c.), Tumbuka (Jean Chavula p.c.), Xhosa (Carstens and Mletshe ms., Du Plessis and Visser 1992), Yao (Whiteley 1966), Zulu (Buell 2007, Zeller 2012).

\section{References}

Abdulaziz, Mohammed. 1996. Transitivity in Swahili. Cologne: Köppe.

Ariel, Mira. 2000. The development of person agreement markers: From pronouns to higher accessibility markers. In Michael Barlow \& Suzanne Kemmer (eds.), Usagebased models of language, 197-260. Stanford: CSLI.

Ashton, Ethel O., E. M. K. Mulira, E. G. M. Ndawula \& A. N. Tucker. 1954. A Luganda grammar. London: Longmans, Green \& Co.

Baker, Mark. 2003. Agreement, dislocation, and partial configurationality. In Andrew Carnie, Heidi Harley \& MaryAnn Willie (eds.), Formal approaches to function in grammar, 107-132. Amsterdam: John Benjamins. 
Baker, Mark. 2008. The syntax of agreement and concord. Cambridge: Cambridge University Press.

Baker, Mark. 2010. Formal Generative Typology. In Bernd Heine \& Heiko Narrog (eds.), The Oxford Handbook of Linguistic Analysis, 285-312. Oxford: Oxford University Press.

Barrett Keach, Camillia N. 1985. The syntax and interpretation of the relative clause construction in Swahili. Amherst, MA: University of Massachusetts $\mathrm{PhD}$ dissertation.

Beaudoin-Lietz, Christa, Derek Nurse \& Sarah Rose. 2004. Pronominal object marking in Bantu. In Akinbiyi Akinlabi \& Oluseye Adesola (eds.), Proceedings of the World Congress of African Linguistics, New Brunswick 2003, 175-188. Cologne: Köppe.

Bonfim Duarte, Fábio. 2011. Tense encoding, agreement patterns, definiteness and relativization strategies in Changana. In Eyamba G. Bokamba et al. (eds.), Selected proceedings of the 40th Annual Conference on African Linguistics, 80-94. Somerville, MA: Cascadilla Proceedings Project.

Bokamba, Eyamba Georges. 1976. Question formation in some Bantu languages. Bloomington, IN: Indiana University PhD dissertation.

Bokamba, Eyamba Georges. 1979. Inversions as grammatical relation changing rules in Bantu languages. Studies in the Linguistic Sciences 9(2). 1-24.

Bostoen, Koen \& Léon Mundeke. 2011. Passiveness and Inversion in Mbuun (Bantu B87, DRC). Studies in Language 35(1). 72-111.

Bostoen, Koen \& Léon Mundeke. 2012. Subject marking, object-verb order and focus in Mbuun (Bantu, B87). Southern African Linguistics and Applied Language Studies 30(2). 139-154. 
Botne, Robert. 2003. Lega (Beya dialect) (D25). In Derek Nurse \& Gérard Philippson (eds.), The Bantu Languages, 422-449. London, Routledge.

Bresnan, Joan \& Jonni M. Kanerva. 1989. Locative inversion in Chichewa: A case study of factorization in grammar. Linguistic Inquiry 20. 1-50.

Bresnan, Joan \& Sam A. Mchombo. 1987. Topic, pronoun, and agreement in Chichewa. Language 63. 741-782.

Bresnan, Joan \& Lioba Moshi. 1990. Object asymmetries in comparative Bantu syntax. Linguistic Inquiry 21. 147-85.

Buell, Leston. 2002. Swahili amba-less relatives without head movement. UCLA Working Papers in Linguistics 8. 86-106.

Buell, Leston. 2007. Semantic and formal locatives: Implications for the Bantu locative inversion typology. SOAS Working Papers in Linguistics 15. 105-120.

Buell, Leston, Kristina Riedel \& Jenneke van der Wal (eds.) 2011. Movement and word order in Bantu. Special issue of Lingua 121(5).

Buell, Leston \& Peter Muriungi. Manuscript. Locatives and locative inversion in Tharaka.

Cann, Ronnie, Ruth Kempson \& Eleni Gregoromichelaki. 2009. Semantics: An introduction to meaning in language. Cambridge: Cambridge University Press.

Carstens, Vicki. 2005. Agree and EPP in Bantu. Natural Language and Linguistic Theory 23(2). 219-279.

Carstens, Vicki \& Loyiso Mletshe. To appear. Implications of Xhosa expletive constructions. Forthcoming in Linguistic Inquiry.

Collins, Chris. 2004. The agreement parameter. In Anne Breitbarth \& Henk van Riemsdijk (eds.), Triggers, 115-136. Berlin: Mouton de Gruyter. 
Crane, Thera Marie, Larry M. Hyman \& Simon Nsielanga Tukumu. 2011. A grammar of Nzadi (B965): a Bantu language of the Democratic Republic of Congo. Berkeley: University of California Press.

Creissels, Denis. 1996. Conjunctive and disjunctive verb forms in Setswana. South African Journal of African Languages 16. 109-115.

Creissels, Denis. 2004. Non-canonical applicatives and focalization in Tswana. Paper presented at Syntax of the World's Languages. Leipzig.

Creissels, Denis. 2011. Tswana locatives and their status in the inversion construction. Africana Linguistica 17. 33-52.

Dalgish, Gerard M. 1976. Locative NP's, locative suffixes and grammatical relations. $B L S$ 2. $139-148$.

de Kind, Jasper \& Koen Bostoen. 2012. The applicative in ciLubà grammar and discourse: A semantic goal analysis. Southern African Linguistics and Applied Language Studies 30(1). 101-124.

Demuth, Katherine. 1989. Maturation and the acquisition of the Sesotho passive. Language 65(1). 56-80.

Demuth, Katherine. 1990. Locatives, impersonals and expletives in Sesotho. The Linguistic Review 7(3). 233-249.

Demuth, Katherine \& Carolyn Harford. 1999. Verb raising and subject inversion in comparative Bantu. Journal of African Languages and Linguistics 20(1). 41-61.

Demuth, Katherine \& Mark Johnson. 1989. Interaction between discourse functions and agreement in Setawana. Journal of African Languages and Linguistics 11. 21-35.

Demuth, Katherine \& Melissa Kline. 2006. The distribution of passives in spoken Sesotho. Southern African Linguistics and Applied Language Studies 24. 377-388. 
Demuth, Katherine \& Sheila Mmusi. 1997. Presentational focus and thematic structure in comparative Bantu. Journal of African Languages and Linguistics 18. 1-19.

Devos, Maud. 2004. A grammar of Makwe. Leiden: Leiden University PhD dissertation.

Diercks, Michael. 2010. Agreement with subjects in Lubukusu. Washington, DC: Georgetown University $\mathrm{PhD}$ dissertation.

Diercks, Michael. 2011. The morphosyntax of Lubukusu locative inversion and the parameterization of Agree. Lingua 121(5). 702-720.

Diercks, Michael. 2012. Parameterizing Case: Evidence from Bantu. Syntax 15(3). 253286.

Dixon, R. M. W. 1997. The rise and fall of languages. Cambridge: Cambridge University Press.

Duranti, Alessandro \& Ernest R. Byarushengo. 1977. On the notion of "direct object". In Ernest R. Byarushengo, Alessandro Duranti \& Larry M. Hyman (eds.), Haya grammatical structure, 45-71. Los Angeles: Department of Linguistics, University of Southern California.

Edelsten, Peter \& Chiku Lijongwa. 2010. A grammatical sketch of Chindamba, a Bantu language (G52) of Tanzania. Cologne: Köppe.

Fortune, George. 1955. An analytical grammar of Shona. London: Longmans, Green and Co.

Gamut, L. T. F. 1991. Logic, language and meaning. 2 vols. Chicago: University of Chicago Press.

Gibson, Hannah. 2008. Half empty or half full: An analysis of subject-object inversion in Swahili. London: SOAS, University of London MA dissertation.

Givón, Talmy. 1976. Topic, pronoun and grammatical agreement. In Charles N. Li (ed.), Subject and topic, 149-188. New York: Academic Press. 
Givón, Talmy. 1979. On understanding grammar. New York: Academic Press.

Gowlett, Derek F. 1989. The parentage and development of Lozi. Journal of African Languages and Linguistics 2. 127-149.

Güldemann, Tom. 2008. Quotative indexes in African languages: A synchronic and diachronic survey. Berlin: Mouton de Gruyter.

Guthrie, Malcolm. 1967-71. Comparative Bantu. 4 vols. Farnborough: Gregg.

Halpert, Claire. 2012. Argument licensing and agreement in Zulu. Boston, MA: MIT PhD dissertation.

Halpert, Claire. To appear. Structural Case and the nature of vP in Zulu. Proceedings of NELS 42. Amherst, MA: GLSA.

Hamlaoui, Fatima \& Emmanuel-Moselly Makasso. 2013. Object left-dislocation, topicalization and the syntax-phonology mapping of intonation phrases in Bàsàa. Presentation at Bantu 5, Paris.

Harford Perez, Carolyn. 1985. Aspects of complementation in three Bantu languages. Madison, WI: University of Wisconsin-Madison PhD dissertation.

Harford, Carolyn (1990): Locative inversion in Chishona. In John Hutchison \& Victor Manfredi (eds.), Current Approaches to African Linguistics, 137-144. Dordrecht: Foris.

Harford, Carolyn \& Katherine Demuth. 1999. Prosody outranks syntax: An Optimality approach to subject inversion in Bantu relatives. Linguistic Analysis 29(1-2). 47-68.

Hawkinson, Annie \& Larry M. Hyman. 1974. Hierarchies of natural topic in Shona. Studies in African Linguistics 5. 147-170.

Henderson, Brent. 2006. The syntax and typology of Bantu relative clauses. UrbanaChampaign. IL: University of Illinois at Urbana-Champaign PhD dissertation.

Henderson, Brent. 2011. Agreement, locality, and OVS in Bantu. Lingua 121(5). 742-753. 
Hopper, Paul J. \& Sandra A. Thompson. 1980. Transitivity in grammar and discourse. Language 56(2). 251-299.

Iorio, David. In progress. Subject and object marking in Bembe. Newcastle: University of Newcastle PhD dissertation.

Janson, Tore. 1991-1992. Southern Bantu and Makua. Sprache und Geschichte in Afrika 12-13. 63-106.

Kashina, Kashina. 2005. The Silozi clause: A study of the structure and distribution of its constituents. Munich: Lincom.

Katamba, Francis. 2003. Bantu nominal morphology. In Derek Nurse \& Gérard Philippson (eds.), The Bantu languages, 103-120. London: Routledge.

Kavari, Jekura, Lutz Marten \& Jenneke van der Wal. 2012. Tone cases in Otjiherero: Head-complement relations, linear order and information structure. Africana Linguistica 18. 315-353.

Kawasha, Boniface. 2007. Passivization in Lunda. Journal of African Languages and Linguistics 28. 37-56.

Kayne, Richard. 2005. Movement and silence. Oxford: Oxford University Press.

Kemmer, Suzanne. 1993. The middle voice. Amsterdam: Benjamins.

Khumalo, Langa. 2010. Passive, locative inversion in Ndebele and the unaccusative hypothesis. South African Journal of African Languages 30. 22-34.

Kimenyi, Alexandre. 1980. A relational grammar of Kinyarwanda. Berkeley, CA: University of California Press.

Kula, Nancy C. \& Lisa Lai-Shen Cheng. 2007. Phonological and syntactic phrasing in Bemba relatives. Journal of African Languages and Linguistics 28(2). 123-148. 
Kula, Nancy C. \& Lutz Marten. 2010. Argument structure and agency in Bemba passives. In Karsten Legère \& Christina Thornell (eds.), Bantu languages: Analyses, description and theory, 115- 130. Cologne: Köppe.

Lakoff, George \& Mark Johnson. 1980. Metaphors we live by. Chicago: University of Chicago Press.

Lambrecht, Knud. 1994. Information structure and sentence form. Cambridge, Cambridge University Press.

Levin, Beth. 1993. English verb classes and alternations. Chicago: The University of Chicago Press.

Maho, Jouni. 1999. A comparative study of Bantu noun classes. Gothenburg: Acta Universitatis Gothoburgensis.

Marten, Lutz. 2003. The dynamics of Bantu applied verbs: An analysis at the syntaxpragmatics interface. In Kézié K. Lébikaza (ed.), Actes du 3e Congrès Mondial de Linguistique Africaine Lomé 2000, 207-221. Cologne: Köppe.

Marten, Lutz. 2006. Locative inversion in Herero: More on morphosyntactic variation in Bantu. In Laura Downing, Sabine Zerbian \& Lutz Marten (eds.), Papers in Bantu grammar and description. ZASPiL 43. 97-122.

Marten, Lutz. 2010. The great siSwati locative shift. In Anne Breitbarth, Christopher Lucas, Sheila Watts \& David Willis (eds.), Continuity and change in grammar, 249267. Amsterdam: Benjamins.

Marten, Lutz. 2011. Information structure and agreement: Subjects and subject markers in Swahili and Herero. Lingua 121(5). 787-804.

Marten, Lutz. 2013. Linguistic variation, language contact and the new comparative Bantu. Inaugural Lecture, SOAS, University of London, 18 April 2013. 
Marten, Lutz \& Hannah Gibson. 2013. Passive, locative inversion and subject-object reversal in Bantu: A unified dynamic analysis. Ms. SOAS, University of London.

Marten, Lutz, Nancy C. Kula \& Nhlanhla Thwala. 2007. Parameters of mophosyntactic variation in Bantu. Transactions of the Philological Society 105. 253-338.

Marten, Lutz \& Deograsia Ramadhani. 2001. An overview of object marking in Kiluguru. SOAS Working Papers in Linguistics and Phonetics 11. 259-275.

Marten, Lutz, Kristina Riedel, Silvester Ron Simango \& Jochen Zeller (eds.). 2012. Special issue of Southern African Linguistics and Applied Language Studies 30(2) on Subject and Object Marking in Bantu.

Mchombo, Sam. 2004. The syntax of Chichewa. Cambridge, Cambridge University Press.

Meeussen, Achille E. 1959. Essai de grammaire Rundi. Tervuren: Annales du Musée Royal du Congo Belge, Serie 8, Sciences de l'Homme, Linguistique, Vol. 24.

Meeussen, Achille E. 1967. Bantu grammatical reconstruction. Africana Linguistica 3. 80-122.

Mkude, Daniel J. 1974. A study of Kiluguru syntax with special reference to the transformational history of sentences with permuted subject and object. London: SOAS, University of London $\mathrm{PhD}$ dissertation.

Möhlig, Wilhelm J. G. 1967. Die Sprache der Dciriku: Phonologie, Prosodologie und Morphologie. Cologne: Universität zu Köln $\mathrm{PhD}$ dissertation.

Möhlig, Wilhelm J.G. \& Jekura U. Kavari. 2008. Reference grammar of Herero (Otjiherero). Cologne: Köppe.

Möhlig, Wilhelm J. G., Lutz Marten \& Jekura U. Kavari. 2002. A grammatical sketch of Herero. Cologne: Köppe.

Morimoto, Yukiko. 2000. Discourse configurationality in Bantu morphosyntax. Stanford, CA: Stanford University PhD dissertation. 
Morimoto, Yukiko. 2006. Agreement properties and word order in comparative Bantu. In Laura Downing, Sabine Zerbian \& Lutz Marten (eds.), Papers in Bantu grammar and description. ZASPiL 43. 161-187.

Moshi, Lioba. 1995. Locatives in KiVunjo-Chaga. In Akibiyi Akinlabi (ed.), Theoretical approaches to African linguistics, 129-146. Trenton, NJ: Africa World Press.

Mugane, John Muratha. 1997. Bantu nominalization structures. Tuscon, AZ: University of Arizona $\mathrm{PhD}$ dissertation.

Muriungi, Peter. 2008. Phrasal movement inside Bantu verbs: deriving affix scope and order in Kî̀tharaka. Tromsø: University of Tromsø PhD dissertation.

Ndayiragije, Juvénal. 1999. Checking economy. Linguistic Inquiry 30. 399-444.

Ngoboka, Jean Paul \& Jochen Zeller. 2013. Locative inversion in Kinyarwanda. Paper presented at the SOAS Inversion Workshop, 25 February 2013.

Ngonyani, Deogratias S. 1996. The morphosyntax of applicatives. Los Angeles, CA:

UCLA PhD dissertation.

Ngonyani, Deo \& Peter Githinji. 2006. The asymmetric nature of Bantu applicative constructions. Lingua 116. 31-63.

Nichols, Johanna. 1992. Linguistic diversity in space and time. Chicago: University of Chicago Press.

Nicolle, Steve. 2013. A grammar of Digo: A Bantu language of Kenya. Dallas, Tex.: SIL International.

Nsuka Nkutsi, Francois. 1982. Les Structures Fondamentales du Relatif dans les Langues Bantoues. Tervuren: Musee Royal de l'Afrique Centrale.

Odden, David. 1984. Formal correlates of focusing in Kimatuumbi. Studies in African Linguistics 15(3). 275-299. 
Odden, David. 1996. The phonology and morphology of Kimatuumbi. Oxford: Clarendon Press.

Pak, Marjorie. 2008. A-movement and intervention effects in Luganda. In Natasha Abner \& Jason Bishop (eds.), Proceedings of the 27th West Coast Conference on Formal Linguistics, 361-369. Somerville, MA: Cascadilla Proceedings Project.

Petzell, Malin. 2008. The Kagulu language of Tanzania: Grammar, texts and vocabulary. Cologne: Köppe.

Riedel, Kristina \& Lutz Marten. 2012. Locative object marking and the argument-adjunct distinction. Southern African Linguistics and Applied Language Studies 30(2). 277292.

Rugemalira, Josephat. 1993. Bantu multiple object constructions. Linguistic Analysis 23. $226-252$

Russell, Joan. 1985. Swahili quasi-passives: The question of context. In Didier L. Goyvaerts (ed.), African linguistics: Essays in memory of M.W.K. Semikenke, 477490. Amsterdam: Benjamins.

Salzmann, Martin. 2001. Theoretical Approaches to Locative Inversion. Zürich: University of Zürich MA dissertation.

Salzmann, Martin. 2011. Towards a typology of locative inversion - Bantu, perhaps Chinese and English - but beyond? Language and Linguistics Compass 5/4. 169189.

Sasse, Hans-Jürgen. 2006. Theticity. In Giuliano Bernini \& Marcia L. Schwartz (eds.), Pragmatic organization of discourse in the languages of Europe, 255-308. Berlin, New York: Mouton de Gruyter.

Schadeberg, Thilo C. 2003. Derivation. In Derek Nurse \& Gérard Philippson (eds.), The Bantu languages, 71-89. London: Routledge. 
Schadeberg, Thilo C. \& Francisco U. Mucanheia. 2000. Ekoti: The Maka or Swahili language of Angoche. Cologne: Köppe.

Stappers, Leo. 1967. Het passief suffix -u- in de Bantoe-talen. Africana Linguistica 3. $139-145$

Thwala, Nhlanhla. 2006a. On the subject-predicate relation and subject agreement in SiSwati. Southern African Linguistics and Applied Language Studies 24(3). 331359.

Thwala, Nhlanhla. 2006b. Parameters of variation and complement licensing in Bantu. In Laura Downing, Sabine Zerbian \& Lutz Marten (eds.), Papers in Bantu grammar and description. ZASPiL 43. 209-232.

Trithart, Mary Lee. 1977. Relational grammar and Chichewa subjectivization. Los Angeles, CA: UCLA MA thesis.

Van der Wal, Jenneke. 2008. Agreement in thetic sentences in Bantu and Romance. In Cécile De Cat \& Katherine Demuth (eds.), The Bantu-Romance connection. A comparative investigation of verbal agreement, DPs and information structure, 323-350. Amsterdam: John Benjamins.

Van der Wal, Jenneke. 2009. Word order and information structure in MakhuwaEnahara. Utrecht: LOT.

Van der Wal, Jenneke. 2012. Subject agreement and the EPP in Bantu agreeing inversion. Cambridge Occasional Papers in Linguistics 6. 201-236.

Van der Wal, Jenneke. Submitted. Parameterising Case: Other evidence from Bantu.

Van Otterloo, Roger. 2011. The Kifuliiru language, volume 2: a descriptive grammar.

Dallas, TX: SIL International.

Visser, Marianna. 1989. The syntax of the infinitive in Xhosa. South African Journal of African Languages 9(4). 154-185. 
Voisin, Sylvie. 2006. Applicatif et emphase. In Daniel Lebaud, Catherine Paulin \& Katja Ploog (eds.), Constructions verbales et production de sens, 155-170. Besançon: Presses Universitaires de Franche-Comté.

Wald, Benji. 1997. Instrumental objects in the history of topicality and transitivity in Bantu. In Rose-Marie Déchaine \& Victor Manfredi (eds.), Object positions in Benue-Kwa, 221-253. The Hague: Holland Academic Graphics.

Whiteley, Wilfred H. 1966. A Study of Yao Sentences. Oxford: Clarendon Press.

Whiteley, Wilfred H. 1972. Case complexes in Swahili. Studies in African Linguistics 3. $1-45$.

Whiteley, Wilfred H. \& J. D. Mganga. 1969. Focus and entailment: Further problems of transitivity in Swahili. African Language Review 8. 108-25.

Woolford, Ellen. 1995. Why passive can block object marking. In Akinbiyi Akinlabi (ed.), Theoretical Approaches to African Linguistics, 199-215. Trenton, New Jersey: Africa World Press.

Yoneda, Nobuko. 2008. Matengo-go no jouhou-kouzou to gojun. Gengo-Kenkyu 133. $107-132$.

Yoneda, Nobuko. 2011. Word order in Matengo (N13): Topicality and informational roles. Lingua 121(5). 754-771.

Zeller, Jochen. 2004. Relative clause formation in the Bantu languages of South Africa. Southern African Linguistics and Applied Language Studies 22. 75-93.

Zeller, Jochen. 2012. Instrument inversion in Zulu. In Michael R. Marlo, Nikki B. Adams, Christopher R. Green, Michelle Morrison \& Tristan M. Purvis (eds.), African languages in context. Selected proceedings of the 42nd Annual Conference on African Linguistics, 134-148. Somerville, MA: Cascadilla Proceedings Project. 
Zeller, Jochen. 2013. Locative inversion in Bantu and predication. Linguistics 51(6), 1107-1146.

Zerbian, Sabine. 2006. Inversion structures in Northern Sotho. Southern African Linguistics and Applied Language Studies 24(3). 361-376.

Ziervogel, Dirk \& Enos John Mabuza. 1976. A grammar of the Swati language. Pretoria: J.L. van Schaik. 


\section{Appendix}

\section{Questionnaire on Bantu subject inversion constructions}

1 May 2013

\section{Background}

Locative inversion is well-documented in Bantu (e.g. Bresnan and Kanerva 1989 and much subsequent work). However, other types of Bantu subject inversion constructions are less well-known. The present research project addresses this question, and we hope that with this questionnaire we can develop a better picture of the empirical situation.

Your contribution is much appreciated and will be duly and gratefully acknowledged in any publications resulting from this research. Please let us know if you have any questions or comments.

\section{Questionnaire}

Please consider the following construction types (there are 8 construction types in total in the questionnaire) and state whether the construction is found in 'your' language - and if 
possible provide an example. For each construction type, we provide an example from a Bantu language where it is found.

\section{1) Formal Locative Inversion}

The preverbal locative expression is formally marked as locative (e.g. in a locative class 16/17/18). The subject marker on the verb agrees with the preverbal locative.

(1) M-òn-djúwó mw-á hìtí é-rùngà.

[Otjiherero]

18-9-house SM18-PST enter 5-thief

'Into the house entered a/the thief.' (Marten 2006)

Please provide an example of a locative inversion construction in your language:

\section{2) Semantic Locative Inversion}

A preverbal DP with locative meaning, but not formally marked as locative (so not in class $16 / 17 / 18)$. The subject marker on the verb agrees with the preverbal locative. 
(2) Lesi sikole si-fund-ela izingane ezikhubazekile. [Zulu]

7.this 7.school SM7-study-APPL 10.children 10.handicapped

'Handicapped children study at this school.' (Buell 2007)

Please provide an example of a semantic locative inversion construction in your language:

\section{3) Instrument Inversion}

The preverbal DP encodes an instrument. The postverbal DP encodes an agent using the instrument. The subject marker on verb agrees with the preverbal instrument in class.

(3) Ikaramu y-andikisha John.

[Kirundi]

9.pen SM9-write John

'It is John who writes with a pen.' (Lit.: 'The pen writes John.')

(Ferdinand Mberamihigo, p.c.)

Please provide an example of an instrument inversion construction in your language: 


\section{4) Purpose Inversion}

The preverbal DP encodes the purpose of performing the action of the verb. The postverbal DP encodes the agent performing the action. The subject marker on verb agrees with the preverbal instrument in class.

(4) Ubutunzi bu-rongoye Baudouin.

[Kirundi]

14.wealth SM14-married Baudouin

'It is Baudouin who married for wealth.' (Lit.: 'Wealth married Baudouin.')

(Ferdinand Mberamihigo, p.c.)

Please provide an example of a purpose inversion construction in your language:

$* * * * * * * * * * * * * * * * * * * *$

\section{5) Theme Inversion (Subject-object Reversal)}

The preverbal DP encodes the theme argument of the verb. The postverbal DP encodes the agent performing the action. The subject marker on verb agrees with the preverbal theme in class. 
(5) Ici-ya ci-tula imw-ana.

7-pot SM7-broke 1-child

'The child broke the pot.' (Lit.: 'The pot broke the child.') (Mkude 1974)

Please provide an example of a theme inversion construction in your language:

\section{6) Complement Clause Inversion}

The preverbal element is a complement clause. The postverbal DP encodes the agent/logical subject. The subject marker on verb may show 'default' agreement. In the example below, the complement clause is shown in square brackets. The default agreement is class 8 .

(6) [Ko abaana b-a-gii-ye] by-iibagiw-e umugore. [Kinyarwanda]

COMP2.child SM2-PST-leave-PRF SM8-forget-PRF woman

'It is the woman (not the man) who forgot that children have left.'

(Lit.: 'That the children left forgot the woman.') (Morimoto 2000:184)

Please provide an example of a complement clause inversion construction in your language: 


\section{7) Locative Presentational Construction}

Typically used to introduce new information, such as a new situation, or new discourse participants. The preverbal element can be omitted, and subject marker on the verb is always the same (invariant) (the subject marker is usually of class 9,16 , or 17).

(7) Hó-lóha bo-nkhó:no

[Sesotho]

SM17-weave 2-grandmother

'There are grandmothers weaving.' (Demuth 1990)

Please provide an example of a locative presentational construction in your language:

\section{8) Agreeing Presentational Construction}

Like locative presentational construction in (7), typically used to introduce new information, such as a new situation, or new discourse participants. The preverbal element 
can be omitted. However, here the subject marker on the verb agrees with the postverbal DP (the agent).

(8) Wa-li-fika wa-toto wa-wili.

[Swahili]

$$
\text { SM2-PST-arrive 2-child 2-two }
$$

'There arrived two children.' (Marten 2010)

Please provide an example of an agreeing presentational construction in your language:

\footnotetext{
${ }^{1}$ Glossing conventions follow the Leipzig Glossing Rules with the following additional abbreviations: 1, 2, 3 etc. $=$ noun class number, $\mathrm{AUG}=$ augment, $\mathrm{CC}=$ complement case, $\mathrm{CJ}=$ conjoint, $\mathrm{DC}=$ default case, $\mathrm{DJ}$ $=$ disjoint, $\mathrm{FV}=$ final vowel, $\mathrm{HAB}=$ habitual, $\mathrm{NAR}=$ narrative, $\mathrm{OM}=$ object marker, $\mathrm{PRO}=$ pronoun, REMIMPV $=$ remote imperfective, $\mathrm{REMPERF}=$ remote perfect, $\mathrm{SM}=$ subject marker. For language names, we generally use names established in British English usage (typically without class prefix, e.g. Swahili), although in some cases where previous scholarship predominantly uses a prefixed form, we use this (e.g. Chichewa).

${ }^{2}$ Denis Creissels (p.c. December 2013) notes that Tswana also allows preverbal agreeing instruments without a postverbal subject, but that this is very limited. It appears that these constructions might be predicate-dependent, being restricted to verbs with meanings like 'stay', 'enter' and 'exit', and may reflect severe lexical underspecification of semantic roles (cf. the discussion of patient inversion with low distinction of semantic roles in Section 4.3, below).

${ }^{3}$ The Ndebele construction in (7) is a default agreement construction (DAI), discussed in more detail below, but behaves with respect to the absence of object marking like formal locative inversion constructions.

${ }^{4}$ In addition, Halpert (2012: 106) shows that that default agreement inversion is possible with ditransitive predicates in Zulu:
}

$$
\begin{array}{llll}
\text { A-ku-thum-el-anga } & \text { muntu } & \text { i-zi-ngane } & \text { mali. } \\
\text { NEG-17SM-send-APPL- NEG.PAST } & \text { 1.person } & \text { AUG-10-child } & 9 . m o n e y \\
\text { 'Nobody sent the children any money.' (Halpert 2012: 106) } &
\end{array}
$$

Further research is needed into the cross-linguistic distribution and information-structural properties of this construction. 


\footnotetext{
${ }^{5}$ It is clear that the postverbal logical subject does not have all the characteristics of the object in the noninverted counterpart, so there is no real 'reversal' of syntactic roles.

${ }^{6}$ Patient inversion in Swahili is not universally accepted, and there appears to be dialectal or individual variation of acceptability (cf. Whiteley 1972: 10, Abdulaziz 1996: 18-20).

${ }^{7}$ This particular type of patient inversion is called 'renversement' in Meeussen (1959: 215) and is reconstructed (as 'anastasis') for Proto-Bantu in Meeussen (1967: 120). See also Levin (1993: 54) on other 'verbs of substance emission' and the so-called 'swarm alternation'.

${ }^{8}$ Cf. Lakoff and Johnson's (1980: 35) The ham sandwich wants his check. We are grateful to David Iorio and Frank Seidel for pointing out this possibility.

${ }^{9}$ Thanks to an anonymous reviewer for suggesting this extra test.

${ }^{10}$ It is unlikely that this is just a preposed topic, however, since in that case we would expect the class 16 subject marker to be used, as this appears in other presentational sentences as well.

${ }^{11}$ This relationship also works the other way around. Matengo does not have a morphological passive strategy and instead uses inverted OVS word order to express a functional passive (cf. Bostoen and Mundeke 2011, Hamlaoui and Makasso 2013):

(i) Lí-híimba ju-li-bweni múundu. 5-lion SM1-OM5-see.PRF 1.person

'A lion has been seen by someone.'

${ }^{12}$ Sources for the languages of the sample are listed in the section on 'Main data sources' at the end of the paper.

${ }^{13} \mathrm{We}$ assume that languages that allow inversion with other predicates also allow it with copulas. This remains a hypothesis to be tested in detail, however.

${ }^{14}$ Note that this does not automatically mean that these languages have Case.

${ }^{15}$ Assertion here refers to the inverted clauses as found in Kirundi and Kinyarwanda.
} 